\title{
Silver(I) coordination complexes and extended networks assembled from $S$, Se, Te substituted acenaphthenes
}

\author{
Fergus R. Knight, ${ }^{* a}$ Rebecca R. M. Randall, ${ }^{a}$ Lucy Wakefield, ${ }^{a}$ Alexandra M. Z. Slawin, ${ }^{a}$ and J. Derek \\ Woollins*
}

\author{
${ }_{5}$ Received (in $\left.X X X, X X X\right)$ Xth $X X X X X X X X X 20 X X$, Accepted Xth XXXXXXXXX 20XX \\ DOI: $10.1039 / b 000000 x$
}

\begin{abstract}
Six related organo-chalconium silver(I) coordination complexes, including two examples of rare organotellurium-silver coordination, have been prepared and structurally characterised by X-ray crystallography. The series of 5-bromo-6-(phenylchalcogeno)acenaphthene ligands L1-L3

$10[\operatorname{Acenap}(\mathrm{Br})(\mathrm{EPh})]($ Acenap $=$ acenaphthene-5,6-diyl; $\mathrm{E}=\mathrm{S}, \mathrm{Se}, \mathrm{Te})$ were independently treated with silver(I) salts $\left(\mathrm{AgBF}_{4}, \mathrm{AgOTf}\right)$. In order to keep the number of variables to a minimum, all reactions were carried out using a 1:1 ratio of $\mathrm{Ag} / \mathrm{L}$ and run in dichloromethane. The nature of the donor atoms and the coordinating ability of the respective counter-anion affects the structural architecture of the final silver(I) complex, generating monomeric, mononuclear, two-coordinate silver(I) complexes $\left\{\left[\mathrm{AgBF}_{4}(\mathrm{~L})_{2}\right](\mathbf{1} \mathrm{L}=\right.$

$\left.\left.{ }_{15} \mathbf{L} \mathbf{2} ; \mathbf{2} \mathrm{L}=\mathbf{L} 2 ; \mathbf{3} \mathrm{L}=\mathbf{L 3}\right)\right\}$, a monomeric three-coordinate silver(I) complex $\left\{\left[\operatorname{AgOTf}(\mathbf{L 2})_{2}\right] \mathbf{5}\right\}$, a monomeric four-coordinate silver(I) complex $\left\{\left[\operatorname{AgOTf}(\mathbf{L} 1)_{3}\right] \mathbf{4}\right\}$ and a $1 \mathrm{D}$ extended helical chain polymer $\left\{[\operatorname{AgOTf}(\mathbf{L 3})]_{n} \mathbf{6}\right\}$. The organic acenaphthene ligands L1-L3 all adopt the same ligation mode with the central silver atom (classical monodentate coordination), which employs a variety of coordination geometries (linear, bent, trigonal planar, tetrahedral).
\end{abstract}

\section{${ }_{20}$ Introduction}

Supramolecular coordination networks assembled from tunable ligands and transition metals have recieved great attention due to their intrinsic structural characteristics and applications in polymer design and materials science. ${ }^{1-6}$ The archetypical design 25 utilises bridging organic ligands as ridgid supports to link central metal ions in an ordered lattice, creating extended, multidimensional networks. ${ }^{4-6}$ Functionalisation of the ligand shell allows the properties, topology and geometry of the extended network to be tailored, allowing new functional 30 materials to be developed. As such, the metal-ligand interaction is an important building block for the design and manufacture of organic solids and metal-organic frameworks (MOFs). ${ }^{4-6}$

Control over the polymeric architecture of the network is, 35 nevertheless a major challenge, governed as it is by additional experimental factors such as the oxidation state of the metal, the coordination geometry, the metal-to-ligand ratio, the nature and spacer length of the bridging ligand, the presence of solvent molecules and the nature of the counter-anions. ${ }^{4,7}$ Subtle 40 modification to any of these parameters can significantly alter the structure of the complexes produced, generating for example classical monomeric, mononuclear species, linear chain polymers or extended three-dimensional networks. ${ }^{4-6}$

45 The diverse coordination chemistry associated with the $\operatorname{Ag}(\mathrm{I})$ ion as a consequence of a $4 d^{10}$ configuration allows for a variety of different coordination geometries to be achieved, thus making silver an attractive and preferred choice of metal for constructing supramolecular networks. ${ }^{4-6,8}$ Furthermore, short $\mathrm{Ag} \cdots \mathrm{Ag}$ 50 contacts between neighbouring metal centres and the greater influence of intermolecular interactions and crystal packing forces associated with a weaker silver-ligand bond contribute to the formation of the extended structure. ${ }^{5,6,8}$ Additional benefits of silver over other metals include the ability to simulatneously bind 55 to hard $(\mathrm{O}, \mathrm{N})^{6,9}$ and soft $(\mathrm{S})^{6,10}$ donor atoms and the availability of a wide range of silver(I) salts, enabling the contribution of the counter-anions in the extended network to be analysed.

The polycyclic aromatic hydrocarbons, naphthalene ${ }^{11}$ and related 60 1,2-dihydroacenaphthylene (acenaphthene) ${ }^{12}$ provide good scaffolds from which to design donor ligands for the construction of metal complexes and extended networks. ${ }^{13}$ The double substitution of groups or atoms at the proximal peri-positions inevitably increases the degree of steric hindrance within the 65 molecule as a result of repulsive interactions resulting from subvan der Waals contacts. ${ }^{14}$ This leads to deformation of the carbon frameworks away from their natural geometry via in-plane and out-of-plane distortions and buckling of the aromatic ring system (angular strain). Metal coordination is therefore favoured inorder 70 to reduce the steric strain and achieve a relaxed geometry without invoking greater molecular distortion. ${ }^{13}$ The ability to tune the donor functionalities enables a variety of coordination modes to be accomplished including classical monodentate, bis- 
monodentate $\mu_{2}$-bridging, bidentate chelating and asymmetric hemilabile coordination. ${ }^{13}$

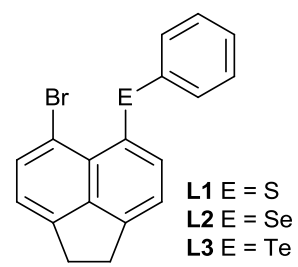

Fig. 1 Acenaphthene bromo-chalcogen donor ligands L1-L3. ${ }^{20}$

5 In a combined study of Group 15 and 16 substituted compounds, we have previously utilised the naphthalene backbone to prepare a variety of chalcogen and phosphorus compounds and associated metal complexes. ${ }^{15-18}$ More recently we have focused on the acenaphthene skeleton investigating chalcogen-tin ${ }^{19}$ compounds 10 and related halogen-chalcogen and chalcogen-chalcogen derivatives. ${ }^{20}$ From a recent study, the series of chalcogen-donor ligands Acenap[EPh][E'Ph] (Acenap = acenaphthene-5,6-diyl; $\mathrm{E} / \mathrm{E}^{\prime}=\mathrm{S}, \mathrm{Se}, \mathrm{Te}$ ) were shown to be ideal building blocks from which to construct coordination networks. Self-assembly with the 15 series of silver(I) salts silver tetrafluoroborate $\left(\mathrm{AgBF}_{4}\right)$, silver trifluoromethanesulfonate (AgOTf) and silver hexafluorophosphate $\left(\mathrm{AgPF}_{6}\right)$ afforded a range of $3 \mathrm{D}$ metalorganic frameworks, 1D polymeric chains and monomeric, mononuclear silver(I) complexes. ${ }^{21}$

Herein we present a similar structural study of the complexes formed between 5-(bromo)-6-(phenylchalcogeno)acenaphthenes $[$ Acenap $(\mathrm{Br})(\mathrm{EPh})]($ Acenap = acenaphthene-5,6-diyl; $\mathrm{E}=\mathrm{S}, \mathrm{Se}$, Te) $\mathbf{L 1}-\mathbf{L 3}^{20}$ (Figure 1) and $\mathrm{AgBF}_{4}$ and AgOTf. The nature of the 25 donor atoms and the coordinating ability of the respective counter-anion affects the structural architecture of the final silver(I) complex, generating two- three- and four- coordinate monomeric, mononuclear silver(I) complexes 1-5 and a 1D extended helical chain polymer $\mathbf{6}$.

30

Whilst coordination complexes formed between organo-sulfur compounds and silver(I) salts are fairly common, those assembled from organo-selenides and organo-tellurides are much rarer. In fact, at the time of writing, a Cambridge Structural ${ }_{35}$ Database (CSD; version 5.33) ${ }^{22}$ search yielded only five examples of organo-tellurium silver(I) complexes. ${ }^{23}$

\section{Results and Discussion}

The series of acenaphthene bromo-chalcogen donor compounds $\{[$ Acenap $(\mathrm{Br})(\mathrm{EPh})]($ Acenap = acenaphthene-5,6-diyl; $\mathrm{E}=\mathrm{S}, \mathrm{Se}$,

$\left.{ }_{40} \mathrm{Te}\right)$ L1-L3 $\}$ were each independently treated with silver tetrafluoroborate $\left[\mathrm{AgBF}_{4}\right]$ and silver trifluoromethanesulfonate [AgOTf]. Reactions were carried out using a 1:1 ratio of $\mathrm{Ag} / \mathbf{L}$ and run in dichloromethane under an oxygen- and moisture-free nitrogen atmosphere. All the complexes obtained (1-6) were 45 characterised by multinuclear NMR and IR spectroscopy and mass spectrometry and the homogeneity of the new compounds was where possible confirmed by microanalysis; ${ }^{77} \mathrm{Se}$ and ${ }^{125} \mathrm{Te}$ NMR data can be found in Table 1. Crystal structures were determined for all six compounds, which were found to be so unstable towards light whilst in solution. Selected interatomic distances, angles and torsion angles are listed in Tables 2 and 3. Further crystallographic information including hydrogen-bond and other non-conventioanl weak inter- and intra-moleular interaction data can be found in Tables S1-S3 and Figures S1-S4 55 in the Electronic Supporting Information (ESI).

Table $1{ }^{77} \mathrm{Se}$ and ${ }^{125} \mathrm{Te}$ NMR spectroscopic data ${ }^{a}$

\begin{tabular}{|c|c|c|c|c|c|c|}
\hline & $\mathbf{L} 2$ & 2 & 5 & L3 & 3 & 6 \\
\hline Peri-atoms & $\mathrm{Br}, \mathrm{Se}$ & $\mathrm{Br}, \mathrm{Se}$ & $\mathrm{Br}, \mathrm{Se}$ & $\mathrm{Br}, \mathrm{Te}$ & $\mathrm{Br}, \mathrm{Te}$ & $\mathrm{Br}, \mathrm{Te}$ \\
\hline${ }^{77} \mathrm{Se} N \mathrm{NMR}$ & 423.7 & 390.6 & 387.8 & - & - & - \\
\hline${ }^{125} \mathrm{Te} \mathrm{NMR}$ & - & - & - & 696.0 & 562.0 & 559.0 \\
\hline
\end{tabular}

$\left[\mathrm{AgBF}_{4}(\mathbf{L 1})_{2}\right]$ 1. Treatment of 5-bromo-6-(phenylsulfanyl)acenaphthene $\mathbf{L 1}^{20}$ with $\mathrm{AgBF}_{4}$ afforded a two-coordinate, 60 monomeric, silver $(\mathrm{I})$ complex $\left[\mathrm{Ag}\left(\mathrm{BF}_{4}\right)\{\operatorname{Acenap}(\mathrm{Br})(\mathrm{SPh})\}_{2}\right] \mathbf{1}$

(Figure 2). Crystals suitable for X-ray diffraction were obtained by slow diffusion of hexane into a saturated solution of the product in dichloromethane, at room temperature in the absence of light. The asymmetric unit contains two silver(I) centres, four 65 sulfur-donor L1 ligands and two tetrafluoroborate counter-anions.

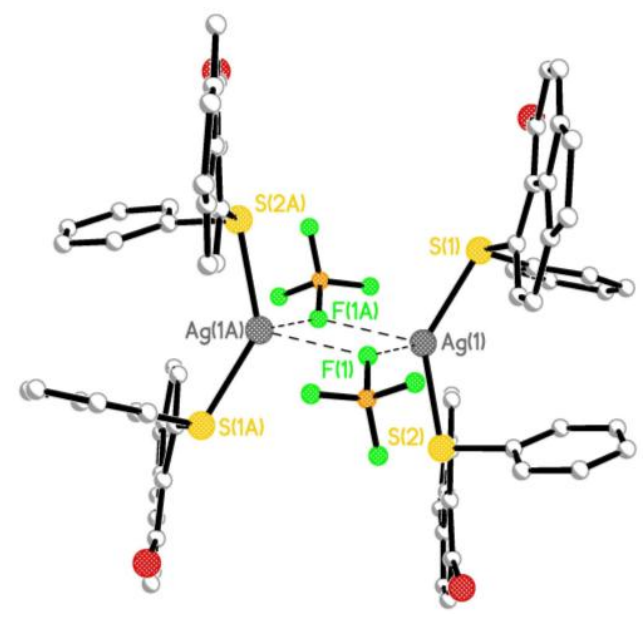

Fig. 2 Two L1 ligands bind to silver(I) via monodentate sulfur coordination to form complex $\mathbf{1}$; two molecules are linked via a central $\mathrm{Ag}_{2} \mathrm{~F}_{2}$ rhombus core formed from weak $\mathrm{Ag} \cdots \mathrm{F}$ contacts 70 ( $\mathrm{H}$ atoms omitted for clarity).

Within the structure, two crystallographically distinct molecules of the sulfur-donor $\mathbf{L} \mathbf{1}$ act as monodentate ligands, binding to silver through $\mathrm{S}$ coordination, affording a two-coordinate 75 monomeric complex. The central silver atom adopts a distorted bent coordination geometry, with an obtuse $\mathrm{S}(1)-\operatorname{Ag}(1)-\mathrm{S}(2)$ angle of $137.19(9)^{\circ}$. Additionally, neighbouring molecules of the silver complex link up to form dimers, joined by an $\mathrm{Ag}_{2} \mathrm{~F}_{2}$ rhombus core formed from weak intermolecular $\mathrm{Ag} \cdots \mathrm{F}$ 80 interactions $\left[\operatorname{Ag}(1) \cdots \mathrm{F}(1) 2.511(9) \AA ; \operatorname{Ag}(1) \cdots \mathrm{F}(1)^{1} 2.563(7) \AA\right.$; Figure 3]. As a consequence of the symmetry the $\mathrm{Ag}_{2} \mathrm{~F}_{2}$ core is strictly planar in the form of a parallelogram containing two unequal Ag $\cdots \mathrm{F}$ bond distances, with the closest non-bonded Ag $\cdots A g$ distance $4.05 \AA$ A In the secondary coordination sphere, 85 the additional intramolecular $\operatorname{Ag}(1) \cdots \mathrm{F}(1)$ contacts complete a quasi-see-saw coordination geometry around each silver centre (Figure 3). 


\section{Cite this: DOI: $10.1039 / \mathrm{c0xx00000x}$}

www.rsc.org/xxxxxx

ARTICLE TYPE

Table 2 Selected interatomic distances $[\AA]$ and angles $\left[{ }^{\circ}\right]$ for 1-6

\begin{tabular}{|c|c|c|c|c|c|c|c|c|c|c|}
\hline \multirow{2}{*}{$\frac{\text { Compound }}{\text { Ligand; peri-atoms }}$} & \multicolumn{2}{|l|}{1} & \multirow{2}{*}{$\frac{2}{\mathbf{L} 2 ; \mathrm{Br}, \mathrm{Se}}$} & \multirow{2}{*}{$\begin{array}{l}\mathbf{3} \\
\mathbf{L 3} ; \mathrm{Br}, \mathrm{Te}\end{array}$} & \multicolumn{3}{|l|}{4} & \multicolumn{2}{|l|}{5} & \multirow{2}{*}{$\begin{array}{l}\mathbf{6} \\
\mathbf{L 3} ; \mathrm{Br}, \mathrm{Te}\end{array}$} \\
\hline & L1a; $\mathrm{Br}, \mathrm{S}$ & $\mathbf{L 1 b} ; \mathrm{Br}, \mathrm{S}$ & & & L1a; $\mathrm{Br}, \mathrm{S}$ & $\mathbf{L 1 b} ; \mathrm{Br}, \mathrm{S}$ & L1c; $\mathrm{Br}, \mathrm{S}$ & L2a; $\mathrm{Br}, \mathrm{Se}$ & $\mathbf{L} \mathbf{2 b} ; \mathrm{Br}, \mathrm{Se}$ & \\
\hline \multicolumn{11}{|l|}{ Peri-region-distances } \\
\hline$\Sigma \mathrm{r}_{\mathrm{vdW}}-\mathrm{Br} \cdots \mathrm{E}^{a} ; \% \Sigma \mathrm{r}_{\mathrm{vdW}}{ }^{a}$ & $0.390 ; 89$ & $0.387 ; 89$ & $0.543 ; 86$ & $0.648 ; 83$ & $0.389 ; 89$ & $0.369 ; 90$ & $0.390 ; 89$ & $0.607 ; 84$ & $0.616 ; 84$ & $0.688 ; 82$ \\
\hline \multicolumn{11}{|l|}{ Peri-region bond angles } \\
\hline $\mathrm{Br}(1)-\mathrm{C}(1)-\mathrm{C}(10)$ & $124.5(8)$ & $121.9(8)$ & $122.7(4)$ & $120.7(6)$ & $123.2(9)$ & $124.1(9)$ & $125.1(8)$ & $123.0(4)$ & $122.6(4)$ & $120.8(10)$ \\
\hline$E(1)-C(9)-C(10)$ & $122.1(10)$ & $121.6(10)$ & $121.7(4)$ & $123.3(6)$ & $123.5(6)$ & $123.9(6)$ & $124.8(6)$ & $122.0(4)$ & $121.4(4)$ & $124.3(8)$ \\
\hline$\Sigma$ of bay angles & $376.3(18)$ & $378.0(18)$ & $377.0(8)$ & $377.5(11)$ & $379.5(15)$ & $379.2(15)$ & $380.3(12)$ & $376.0(7)$ & $375.5(8)$ & $376.3(17)$ \\
\hline Splay angle ${ }^{b}$ & 16.3 & 18.0 & 17.0 & 17.5 & 19.5 & 19.2 & 20.3 & 16.0 & 15.5 & 16.3 \\
\hline \multicolumn{11}{|l|}{ Out-of-plane displacement } \\
\hline $\mathrm{Br}$ & $-0.306(1)$ & $-0.190(1)$ & $0.135(1)$ & $0.101(1)$ & $-0.277(1)$ & $-0.030(1)$ & $0.166(1)$ & $-0.020(1)$ & $0.091(1)$ & $0.039(1)$ \\
\hline
\end{tabular}

Coordination to silver has no significant effect on the 5 conformation of the acenaphthene components or the degree of molecular distortion occurring within the organic framework compared with the parent donor ligand L1. ${ }^{20}$ The two independent acenaphthene fragments $(\mathbf{L 1 a} / \mathbf{L 1 b})$ adopt similar axial conformations; ${ }^{25}$ in each case aligning the $\mathrm{S}-\mathrm{C}_{\mathrm{Ph}}$ bond 10 perpendicular to the organic backbone corresponding to a type $\mathrm{A}$

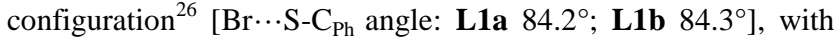
the bulk of the phenyl moiety directed away from the central $\mathrm{Ag}_{2} \mathrm{~F}_{2}$ rhombus core.
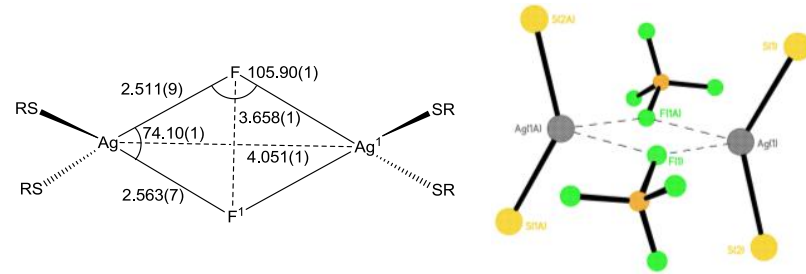

15 Fig. 3 A schematic representation of the $\mathrm{Ag}_{2} \mathrm{~F}_{2}$ rhombus core; $\mathrm{SR}=$ [Acenap $(\mathrm{Br}(\mathrm{SPh})]$, bond distances $[\AA]$, angles $\left[{ }^{\circ}\right]$

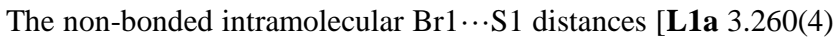
$\AA$; L1b 3.263(3) $\AA$ ] are $11 \%$ shorter than the sum of the van der Waals radii for the two peri-atoms and comparable to the free 20 ligand L1 (3.297(3) $\AA$ ).$^{20}$ Whilst there is a minor decrease in the degree of in-plane distortion [splay angle: L1a $16.3^{\circ}$; L1b $18.0^{\circ}$; cf. $\mathbf{L} 120.3^{\circ}$ ], this is compensated for by an increase in the displacement of the two peri-atoms from the mean acenaphthene plane [L1a/L1b 0.2-0.6 $\AA$; $c f . \mathbf{L 1 ~} \sim 0.1 \AA] .{ }^{20}$ Additionally, there is 25 a notable increase in the buckling of the organic framework of both acenaphthene components, with maximum $\mathrm{C}-\mathrm{C}-\mathrm{C}-\mathrm{C}$ central torsion angles $3-7^{\circ}\left(c f . \mathbf{L} \mathbf{1} 1-3^{\circ}\right) .^{20}$

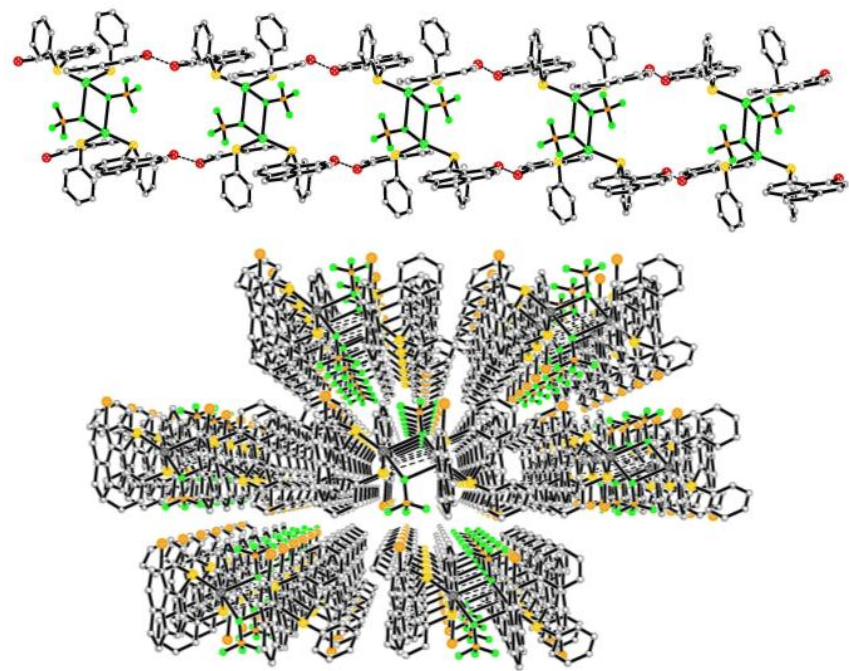

30 Fig. 4 Neighbouring molecules of 1 connect via weak $\mathrm{Br} \cdots \mathrm{Br}$ interactions forming extended chains (top) which pack in parallel columns (bottom)

Dimer molecules of $\mathbf{1}$ assemble in parallel columns and are linked by weak intermolecular $\operatorname{Br}(1) \cdots \operatorname{Br}(2)(3.428 \AA)$ and $\mathrm{C}(19)$ $\operatorname{Br}(2) \cdots \operatorname{cg}(13-18)$ (3.99 $\AA$ ) interactions to form extended chains 35 (Figure 4). Within each chain, the planar $\mathrm{Ag}_{2} \mathrm{~F}_{2}$ rhombus cores stack to form layers, separated by $10.29 \AA$. Adjacent chains interact via weak $\mathrm{CH} \cdots \pi$ interactions $[\mathrm{C}(15)-\mathrm{H}(15) \cdots \operatorname{cg}(5-10)$ $2.96 \AA]$ and short $\mathrm{C}(29)-\mathrm{H}(29) \cdots \mathrm{S}(1)$ contacts $(2.85 \AA)$, with the $\mathrm{BF}_{4}^{-}$counter-anions lying in holes between adjacent 40 acenaphthene frameworks. 


\section{Cite this: DOI: $10.1039 / \mathrm{c0xx00000x}$}

\section{www.rsc.org/XXXXXX}

\section{ARTICLE TYPE}

Table 3 Selected silver coordination interatomic distances $[\AA ̊]$ and angles $\left[{ }^{\circ}\right]$ for 1-6

\begin{tabular}{|c|c|c|c|c|c|c|c|}
\hline 1 & & & & 2 & & 3 & \\
\hline $\operatorname{Ag}(1)-S(1)$ & $2.481(4)$ & $\mathbf{S}(1)-\operatorname{Ag}(1)-S(2)$ & 137.19(9) & $\operatorname{Ag}(1)-\operatorname{Se}(1)$ & $2.5596(13)$ & $\operatorname{Ag}(1)-\operatorname{Te}(1)$ & $2.6572(9)$ \\
\hline $\operatorname{Ag}(1)-S(2)$ & $2.488(3)$ & $\mathbf{S}(\mathbf{1})-\mathbf{A g}(\mathbf{1})-\mathbf{F}(\mathbf{1})$ & $109.79(1)$ & $\operatorname{Ag}(1) \cdots \operatorname{Br}(1)$ & $3.2506(12)$ & $\operatorname{Ag}(1) \cdots \operatorname{Br}(1)$ & $3.4993(12)$ \\
\hline $\operatorname{Ag}(1) \cdots F(1)$ & $2.511(9)$ & $S(1)-\operatorname{Ag}(1)-F(1)^{1}$ & $108.60(1)$ & $\operatorname{Se}(1)-\operatorname{Ag}(1)-\operatorname{Se}(1)^{1}$ & $167.37(3)$ & $\operatorname{Te}(1)-\operatorname{Ag}(1)-\operatorname{Te}(1)^{1}$ & $167.68(5)$ \\
\hline $\operatorname{Ag}(1) \cdots F(1)^{1}$ & $2.563(7)$ & $S(2)-\operatorname{Ag}(1)-F(1)$ & $97.81(1)$ & $\operatorname{Se}(1)-\operatorname{Ag}(1)-\operatorname{Br}(1)$ & $65.75(1)$ & $\operatorname{Te}(1)-\operatorname{Ag}(1)-\operatorname{Br}(1)$ & $62.24(1)$ \\
\hline $\operatorname{Ag}(1) \cdots \operatorname{Ag}(1)^{1}$ & 4.051(1) & $S(2)-\operatorname{Ag}(1)-F(1)^{1}$ & $110.13(1)$ & $\operatorname{Se}(1)-\operatorname{Ag}(1)-\operatorname{Br}(1)^{1}$ & $108.15(1)$ & $\operatorname{Te}(1)-\operatorname{Ag}(1)-\operatorname{Br}(1)^{1}$ & $111.04(1)$ \\
\hline \multirow[t]{2}{*}{$\mathbf{F}(\mathbf{1}) \cdots \mathbf{F}(\mathbf{1})^{1}$} & $3.058(1)$ & $F(1)-\operatorname{Ag}(1)-F(1)^{1}$ & $74.10(1)$ & $\operatorname{Br}(1)-\operatorname{Ag}(1)-\operatorname{Br}(1)^{1}$ & $126.39(3)$ & $\operatorname{Br}(1)-\operatorname{Ag}(1)-\operatorname{Br}(1)^{1}$ & $120.28(1)$ \\
\hline & & $\operatorname{Ag}(1)-F(1)-A g(1)^{1}$ & $105.90(1)$ & \multicolumn{4}{|l|}{6} \\
\hline \multicolumn{4}{|l|}{4} & $\operatorname{Ag}(1)-\operatorname{Te}(1)$ & $2.6714(15)$ & $\operatorname{Te}(1)-\operatorname{Ag}(1)-O(1)$ & $135.04(19)$ \\
\hline $\operatorname{Ag}(1)-S(1)$ & $2.506(3)$ & $\mathbf{S}(1)-\operatorname{Ag}(1)-\mathbf{S}(3)$ & $119.05(7)$ & $\operatorname{Ag}(1)-O(1)$ & $2.377(9)$ & $\operatorname{Te}(1)-\operatorname{Ag}(1)-O(2)$ & $117.62(1)$ \\
\hline $\operatorname{Ag}(1)-S(2)$ & $2.569(3)$ & $\mathbf{S}(2)-\mathbf{A g}(1)-\mathbf{S}(3)$ & $97.73(9)$ & $\operatorname{Ag}(1) \cdots O(2)^{2}$ & $2.469(9)$ & $\operatorname{Te}(1)-\operatorname{Ag}(1)-O(3)$ & $114.75(1)$ \\
\hline $\operatorname{Ag}(1)-S(3)$ & 2.591(3) & $\mathbf{S}(\mathbf{1})-\operatorname{Ag}(\mathbf{1})-\mathbf{O}(\mathbf{1})$ & 109.2(3) & $\operatorname{Ag}(1) \cdots O(3)^{1}$ & $2.778(10)$ & $\mathbf{O}(1)-\operatorname{Ag}(1)-O(2)$ & $81.17(1)$ \\
\hline $\operatorname{Ag}(1)-O(1)$ & $2.395(10)$ & $S(2)-\operatorname{Ag}(1)-O(1)$ & $96.4(2)$ & $\operatorname{Ag}(1) \cdots O(3)^{3}$ & $2.518(9)$ & $\mathbf{O}(\mathbf{1})-\operatorname{Ag}(1)-\mathbf{O}(3)$ & $78.53(1)$ \\
\hline $\mathbf{S}(\mathbf{1})-\mathbf{A g}(\mathbf{1})-\mathbf{S}(2)$ & $127.83(9)$ & $\mathbf{S}(3)-\operatorname{Ag}(\mathbf{1})-\mathbf{O}(\mathbf{1})$ & $102.0(3)$ & $\operatorname{Ag}(1) \cdots \operatorname{Ag}(1)^{1}$ & $3.542(3)$ & $\mathbf{O}(2)-\operatorname{Ag}(1)-\mathbf{O}(3)$ & $122.40(1)$ \\
\hline \multicolumn{8}{|l|}{5} \\
\hline $\operatorname{Ag}(1)-\operatorname{Se}(1)$ & $2.5952(9)$ & $\operatorname{Ag}(1) \cdots \operatorname{Br}(1)$ & $3.1921(13)$ & $\operatorname{Se}(1)-\operatorname{Ag}(1)-\operatorname{Se}(2)$ & $137.30(3)$ & $\operatorname{Br}(1)-\operatorname{Ag}(1)-O(1)$ & $75.01(1)$ \\
\hline $\operatorname{Ag}(1)-\operatorname{Se}(2)$ & $2.5923(9)$ & $\operatorname{Ag}(1) \cdots \operatorname{Br}(2)$ & $3.3524(13)$ & $\operatorname{Se}(1)-\operatorname{Ag}(1)-O(1)$ & $112.81(9)$ & $\operatorname{Se}(2)-\operatorname{Ag}(1)-\operatorname{Br}(2)$ & $62.08(1)$ \\
\hline \multirow[t]{2}{*}{$\operatorname{Ag}(1)-O(1)$} & $2.382(4)$ & $\operatorname{Se}(1)-\operatorname{Ag}(1)-\operatorname{Br}(1)$ & $64.82(1)$ & $\operatorname{Se}(2)-\operatorname{Ag}(1)-O(1)$ & $109.88(9)$ & $\operatorname{Br}(2)-\operatorname{Ag}(1)-O(1)$ & $73.54(1)$ \\
\hline & & $\operatorname{Se}(1)-\operatorname{Ag}(1)-\operatorname{Br}(2)$ & $130.53(1)$ & $\operatorname{Br}(1)-\operatorname{Ag}(1)-\operatorname{Br}(2)$ & $148.52(1)$ & $\operatorname{Br}(1)-\operatorname{Ag}(1)-\operatorname{Se}(2)$ & $129.67(1)$ \\
\hline
\end{tabular}

$\left[\begin{array}{lllllll}\left.\mathrm{AgBF}_{4}(\mathbf{L 2})_{2}\right] & \mathbf{2} & \& & {\left[\mathrm{AgBF}_{4}(\mathbf{L 3})_{2}\right]} & 3 . & \text { Reaction of the }\end{array}\right.$ corresponding selenium and tellurium analogues [Acenap $(\mathrm{Br})(\mathrm{SePh})] \quad \mathbf{L 2}^{20}$ and $[\mathrm{Acenap}(\mathrm{Br})(\mathrm{TePh})] \mathbf{L 3}^{20}$ with $5 \mathrm{AgBF}_{4}$ afforded two isomorphous monomeric two-coordinate silver(I) complexes $\left[\mathrm{Ag}\left(\mathrm{BF}_{4}\right)\{\mathrm{Acenap}(\mathrm{Br})(\mathrm{EPh})\}_{2}\right](2 \mathrm{E}=\mathrm{Se} ; \mathbf{3} \mathrm{E}$ $=$ Te; Figure 5). Crystals of $\mathbf{2}$ suitable for X-ray diffraction were obtained by recrystallization from diffusion of hexane into a saturated acetone solution, whilst crystals of $\mathbf{3}$ were obtained 10 from hexane/dichloromethane. Recrystallisations of both products were performed at room temperature, in the absence of light to prevent the complexes from decomposing.

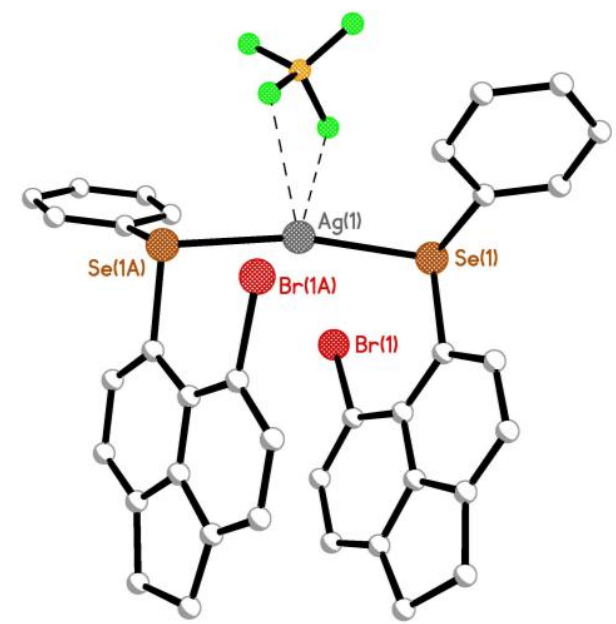

Fig. 5 The two-coordinate mononuclear complex 2 ( $\mathrm{H}$ atoms omitted for 15 clarity). The structure of $\mathbf{3}$ (adopting the same configuration) is omitted here but can be found in Figure S1 in the ESI
The nearly identical asymmetric units contain four silver(I) centres, eight chalcogen $\mathbf{L} \mathbf{2} / \mathbf{L} 3^{20}$ ligands and four tetrafluoroborate counter-anions (disordered in 3). As a 20 consequence of the symmetry (crystallising in the monoclinic $\mathrm{C} 2 / \mathrm{c}$ space group) and in contrast with complex $\mathbf{1}$, only one crystallographically independent ligand is present in each crystal structure; two crystallographically identical molecules of the respective ligand $(\mathbf{L} 2 / \mathbf{L} 3)$ bind with silver, via monodentate $\mathrm{E}$ 25 coordination, to afford the monomeric complex [2 $\mathrm{Ag}(1)-\mathrm{Se}(1)$

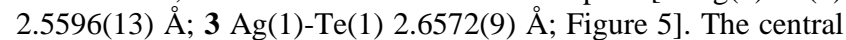
silver atom adopts a quasi-linear coordination geometry with an $\mathrm{E}(1)-\mathrm{Ag}(1)-\mathrm{E}(1)$ angles of 167.37(3) $\AA(2 \mathrm{E}=\mathrm{Se})$ and 167.68(5) $\AA(3 \mathrm{E}=\mathrm{Te})$. In the secondary coordination sphere, additional 30 intramolecular $\operatorname{Ag}(1) \cdots \operatorname{Br}(1)$ contacts $\left[\begin{array}{lll}2 & 3.2506(12) & \AA\end{array} ; \quad 3\right.$ $3.4993(12) \AA]$, complete a quasi-chelate ring with the central silver atom which assumes a distorted see-saw geometry in both complexes $\left[\mathrm{Br}(1)-\mathrm{Ag}(1)-\mathrm{Br}(1)^{1} 2\right.$ 126.39(3) ${ }^{\mathrm{o}} ; 3$ 120.28(1) ${ }^{\mathrm{o}}$; $\mathrm{E}(1)-$ $\operatorname{Ag}(1)-\operatorname{Br}(1) \quad 2 \quad 65.75(1)^{\circ} ; \quad 3 \quad 62.24(1)^{\circ} ; \quad \mathrm{E}(1)-\operatorname{Ag}(1)-\operatorname{Br}(1)^{1} \quad 2$ 35 108.15(1) ${ }^{\mathbf{o}} ; 3$ 111.04(1) ${ }^{\mathbf{o}}$; Figure 6].
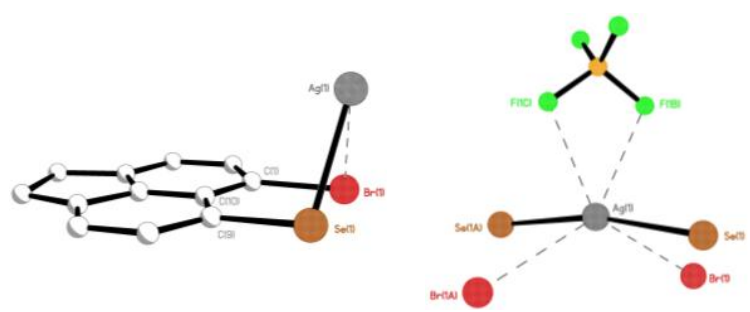

Fig. 6 The open envelope configuration of the pseudo-chelate ring formed by weak intramolecular $\mathrm{Br} \cdots \mathrm{Ag}$ interactions (left) and the central seesaw geometry around $\operatorname{Ag}(1)$ afforded by interactions in the secondary 40 coordination sphere. Comparable images of $\mathbf{3}$ are omitted here but can be found in Figure S2 in the ESI. 
The $\mathrm{AgBrEC}_{3}$ six-membered chelate rings subsequently formed adopt twisted envelope type conformations, hinged about the $\mathrm{Br} \cdots \mathrm{E}$ vectors; $\mathrm{Br}(1), \mathrm{E}(1), \mathrm{C}(1), \mathrm{C}(9), \mathrm{C}(10)$ are essentially 5 coplanar in each case [mean deviation 2 0.0371(1) $\AA$; 3 0.0371(1) $\AA]$ with the silver atom sitting in the peri-gap, displaced $2.334(1)$ $\AA$ and 2.500(1) $\AA$ above this plane respectively, with the $\operatorname{Ag}(1)$ $\mathrm{Br}(1)-\mathrm{E}(1)$ planes inclined by $101.30(1)^{\circ}$ and $100.32(1)^{\circ}$ (Figure $6)$. In both complexes, additional weak intermolecular $\mathrm{Ag} \cdots \mathrm{F}$ 10 interactions link the silver centre to a single $\mathrm{BF}_{4}{ }^{-}$counteranion, positioned directly above the molecule $[2 \mathrm{~F}(1) \cdots \operatorname{Ag}(1) 2.737(4)$

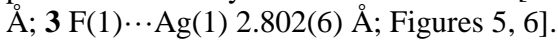

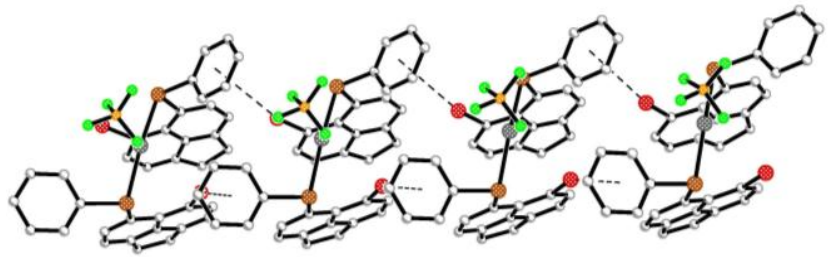

Fig. 7 Complexes 2 and $\mathbf{3}$ pack along the x-axis with neighbouring 15 molecules linked via weak $\mathrm{CBr}^{\cdots} \pi$ type interactions to form extended chains. Complex $\mathbf{2}$ shown here, a similar image for $\mathbf{3}$ can be found in the ESI.

Whilst coordination to silver has no apparent influence on the acenaphthene configurations of either complex (both adopt 20 equatorial arrangements similar to $\mathbf{L 2 / L 3}),{ }^{20,25}$ the pseudobidentate coordination forces the peri-atoms in $\mathbf{2}$ to lie further apart compared to the free ligand [splay angle: $217.0^{\circ} ; c f$. L2 $\left.14.6^{\circ}\right],{ }^{20}$ subsequently elongating the non-bonding intramolecular $\operatorname{Br}(1) \cdots \operatorname{Se}(1)$ peri-distance from $3.1588(16) \AA$ in $\mathbf{L 2}^{20}$ to $253.2068(13) \AA$ in 2 . Notably less molecular distortion is required to accommodate the silver atom in $\mathbf{3}$ due to the greater degree of distortion occurring naturally by the presence of the larger tellurium heteroatom; only a minor lengthening of the peri-gap is observed compared with the free ligand $\mathbf{L 3}[\operatorname{Br}(1) \cdots \mathrm{Te}(1) \mathbf{3}$ 30 3.2625(12) $\AA$; L3 3.2503(11) $\mathrm{A}] .{ }^{20}$ Nevertheless, both complexes exhibit an increase in the planarity of the organic backbone [maximum C-C-C-C torsion angles: $\mathbf{2 / 3} 2^{\circ}$; $c$. $\mathbf{L} 2 / \mathbf{L} 35^{\circ}$ ] and a reduction in the displacement of the peri-atoms to opposite sides of the mean plane [ 2/3 0.1 $\AA$; $c f$. L2 0.3-0.4 $\AA^{2}$. ${ }^{20 \text { Error! Bookmark not }}$ 35 defined.

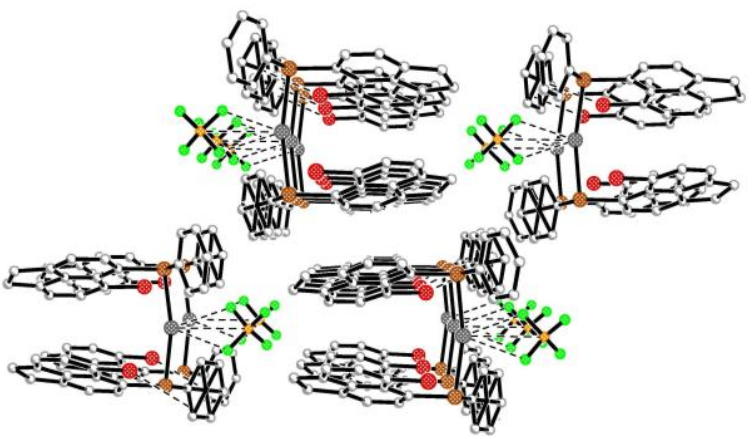

Fig. 8 Packing of complex 2 viewed along the $\mathrm{x}$-axis ( $\mathrm{H}$ atoms omitted for clarity). A comparable image of $\mathbf{3}$ can be found in the ESI.

Within the extended structure of both complexes, neighbouring 40 molecules stack along the $\mathrm{x}$-axis and connect via weak intermolecular $\mathrm{C}-\mathrm{Br} \cdots \pi$ interactions $[\mathrm{C}(1)-\mathrm{Br}(1) \cdots \operatorname{cg}(13-18) 2$
$3.64 \AA ; 23.71 \AA$ ] forming extended chains (Figure 7). Silver atoms subsequently align in columns, with the closest $\mathrm{Ag} \cdots \mathrm{Ag}$ distances between adjacent silver atoms of 7.943(1) $\AA$ (2) and $457.970(1) \AA$ (3). The non-coordinating $\mathrm{BF}_{4}{ }^{-}$counter-anions lie in the channels between the acenaphthene moieties and interact with the organic framework via additional $\mathrm{CH} \cdots \mathrm{F}$ interactions [2.262.51 Å; Figure 8].

50 In contrast to the tetrafluroborate anion, the coordinating ability of the trifluoromethanesulfonate (triflate) counter-anion has a significant impact on the self-assembly of the Acenap $(\mathrm{Br})(\mathrm{EPh})$ donor ligands with AgOTf and dictates the topology and geometric architecture of the final solid state structures.

55

[AgOTf(L1) $)_{3}$ 4. The reaction between $[$ Acenap $(\mathrm{Br})(\mathrm{SPh})] \mathbf{L 1}^{20}$ and AgOTf afforded a four-coordinate, mononuclear silver(I) complex $\left[\mathrm{Ag}(\mathrm{OTf})\{\operatorname{Acenap}(\mathrm{Br})(\mathrm{SPh})\}_{3}\right] 4$ (Figure 9). Crystals suitable for $\mathrm{X}$-ray diffraction were obtained by recrystallization 60 from diffusion of hexane into a saturated dichloromethane solution of the product in the absence of light, at room temperature. The asymmetric unit of $\mathbf{4}$ contains two silver(I) centres, six $\mathbf{L} \mathbf{1}$ ligands and two disordered triflate counter-anions.

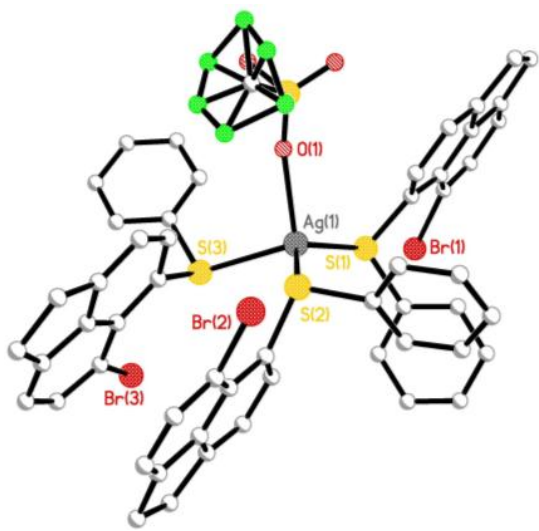

$65 \quad$ Fig. 9 The four-coordinate mononuclear complex 4 with disordered triflate counter-anion ( $\mathrm{H}$ atoms omitted for clarity).

In contrast to complex $\mathbf{1}$, the capacity of the trifluoromethanesulfonate (triflate) counter-anion to coordinate to silver has a significant impact on the geometry and molecular 70 configuration of the final solid state structure. Three crystallographically distinct molecules of the sulfur-donor ligand (L1a-L1c) bind to silver via monodentate $\mathrm{S}$ coordination, with an additional Ag-O bond to the coordinating disordered triflate anion completing a distorted tetrahedral geometry around the central

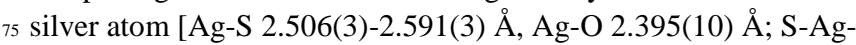
S/S-Ag-O 96.4(2) ${ }^{\circ}-127.83(9)^{\circ}$; Figure 9].

The three independent acenaphthene ligands (L1a-L1c) each adopt similar axial conformations (type A), ${ }^{25,26}$ aligning the $\mathrm{S}-\mathrm{C}_{\mathrm{Ph}}$ 80 bond perpendicular to the mean plane of the organic backbone, with the pheynl rings pointing away from the centre of the molecule. Similar to complex $\mathbf{1}$, coordination to silver has a limited impact on the degree of molecular distortion occurring in L1a-L1c compared with the free ligand $\mathbf{L 1},{ }^{20}$ with non-bonded 85 intramolecular $\mathrm{Br} \cdots \mathrm{S}$ distances 3.260(3)-3.281(3) $\AA$ compared with $3.297(3) \AA$ in $\mathbf{L 1}{ }^{20}$ Two non-bonded intramolecular $\mathrm{CH} \cdots \mathrm{F}$ 


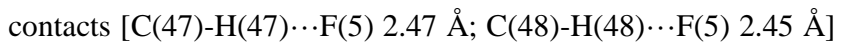
align the triflate molecule along the mean plane of acenaphthene fragment L1c adding extra stability to the structure (Figure 10). Silver centres of neighbouring molecules align in columns along 5 the $\mathrm{x}$-axis, with the closest intermolecular $\mathrm{Ag} \cdots \mathrm{Ag}$ distance 9.297(1) $\AA$. Adjacent molecules of $\mathbf{4}$ interact via weak intermolecular $\mathrm{C}(42)-\mathrm{H}(42) \cdots \mathrm{Br}(1)$ interactions $(2.91 \AA)$ with further short contacts linking acenaphthene backbones to proximal triflate anions $[\mathrm{C}(57)-\mathrm{H}(57) \cdots \mathrm{F}(6) 2.35 \AA$ A $\mathrm{C}(57)$ ${ }_{10} \mathrm{H}(57) \cdots \mathrm{O}$ (3) $2.38 \AA$ ].

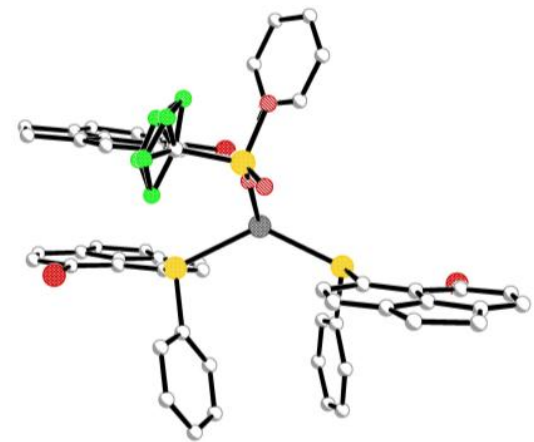

Fig.10 Weak $\mathrm{CH} \cdots \mathrm{F}$ type interactions align the triflate molecule along the plane of the second acenphthene ring.

[AgOTf(L2) $)_{2}$ 5. The corresponding reaction between the 15 heavier selenium ligand $\mathbf{L 2}^{20}$ with AgOTf afforded a threecoordinate complex $\left[\mathrm{Ag}(\mathrm{OTf})\{\operatorname{Acenap}(\mathrm{Br})(\mathrm{SePh})\}_{2}\right] 5$ (Figure 11). Crystals suitable for $X$-ray diffraction were obtained by recrystallization from diffusion of hexane into a saturated acetone solution of the product at room temperature, in the absence of 20 light. The asymmetric unit contains two silver(I) centres, four selenium L2 ligands and two coordinating triflate counter-anions.

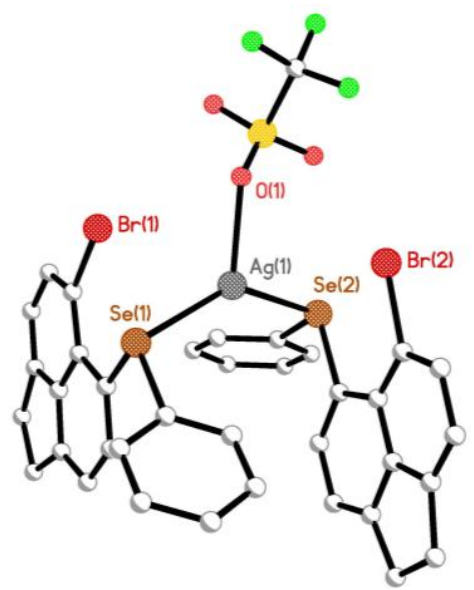

Fig.11 The three-coordinate monomeric, mononuclear complex $5(\mathrm{H}$ atoms omitted for clarity)

25 The three-coordinate complex $\mathbf{5}$ adopts a comparable structure to 2, with subtle differences accounted for by the coordinating ability of the triflate counter anion. In contrast with $\mathbf{2}$, two crystallographically distinct molecules of $\mathbf{L 2}$ bind to the central silver atom via similar monodentate Se coordination $[\mathrm{Ag}(1)-\mathrm{Se}(1)$ 30 2.5952(9) ̊; $\operatorname{Ag}(1)-\operatorname{Se}(2)$ 2.5923(9) $\AA]$. The triflate counteranion occupies a similar position to the $\mathrm{BF}_{4}{ }^{-}$anion in $\mathbf{2}$, however, coordination to silver via a single $\mathrm{O}$ atom completes a trigonal planar geometry around the central metal $[\mathrm{Ag}(1)-\mathrm{O}(1) 2.382(4)$

$\AA$; $\operatorname{Se}(1)-\operatorname{Ag}(1)-\operatorname{Se}(2)$ 137.30(3) ̊; Se(1)-Ag(1)-O(1) 112.81(9) ${ }_{35} \AA$; $\mathrm{Se}(2)-\mathrm{Ag}(1)-\mathrm{O}(1)$ 109.88(9) $\AA$; Figure 12].

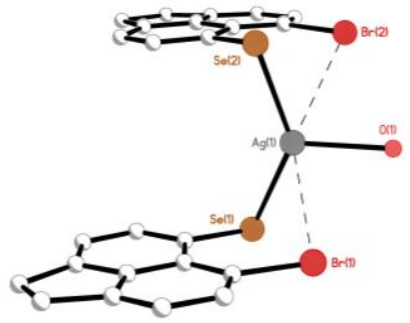

Fig. 12 In the primary coordination sphere the central silver metal adopts a trigonal planar geometry, with supplementary weak $\mathrm{Br} \cdots \mathrm{Ag}$ contacts

completing a trigonal bipyramidal configuration and forming two 40 comparable 6-membered chelate rings ( $\mathrm{H}$ atoms and phenyl rings omitted for clarity).

To accommodate the change in metal coordination in $\mathbf{5}$, rotation around the $\mathrm{Ag}(1)-\mathrm{Se}(2)$ bond positions the non-bonded $\mathrm{Br} \cdots \mathrm{Se}$ interaction of $\mathbf{L 2 b}$ quasi-perpendicular to that of L2a, whilst 45 maintaining a parallel alignment of the two acenaphthene backbones ( $c f .2$ the two acenaphthene planes and periinteractions align parallel to one another). The equatorial arrangement adopted by $\mathbf{L 2 a}$ and $\mathbf{L 2} \mathbf{b},{ }^{25}$ aligning the $\mathrm{Se}-\mathrm{C}_{\mathrm{Ph}}$ bonds along the respective acenaphthene plane, subsequently 50 positions both phenyl rings in close proximity to the neighbouring acenaphthene ring, allowing short intramolecular $\mathrm{CH} \cdots \pi$ interactions to stabilise the molecule [C(14)$\mathrm{H}(14) \cdots \operatorname{cg}(23-28) \quad 2.90 \AA$; Figure 12]. The two non-bonded Br..Se distances [L2a 3.1427(11) $\AA$; L2b 3.1337(11) $\AA$ ] are 55 comparable to the free ligand $\mathbf{L 2}(3.1588(16) \AA)^{20}$ suggesting the three-coordinate geometry around silver in $\mathbf{5}$ has less of an impact on the acenaphthene framework compared with complex 2 .

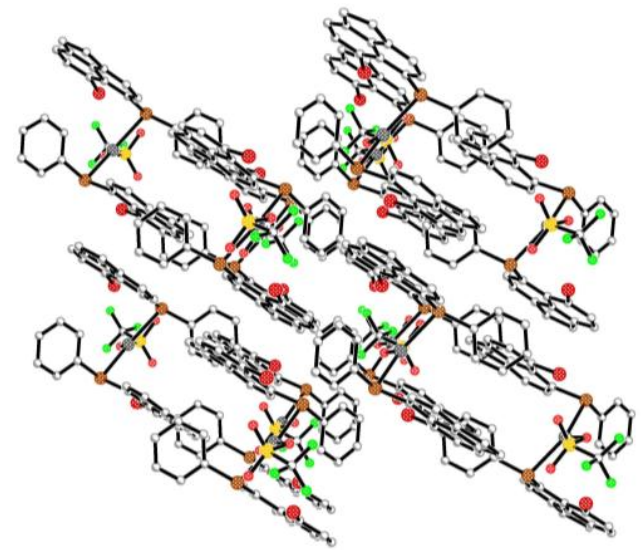

Fig. 13 Weak $\mathrm{CH} \cdots \mathrm{F}$ and $\mathrm{CH} \cdots \mathrm{O}$ interactions link triflate molecules to 60 the organic frameworks of neighbouring molecules to form extended chains; packing of $\mathbf{5}$ as viewed down the y-axis ( $\mathrm{H}$ atoms omitted for clarity).

Supplementary intramolecular $\mathrm{Ag} \cdots \mathrm{Br}$ contacts $[\mathrm{Ag}(1) \cdots \mathrm{Br}(1)$ 3.1921(13) $\AA$; $\operatorname{Ag}(1) \cdots \operatorname{Br}(2) 3.3524(13) \AA]$ allow the two unique ${ }_{65} \mathbf{L 2}$ molecules to attain a quasi-chelate ring, with the central silver atom assuming a distorted trigonal bipyramidal coordination geometry (Figure 12). The two comparable $\mathrm{AgBrSeC}_{3}$ sixmembered twisted envelope type chelate ring systems hinge about the $\mathrm{Br} \cdots \mathrm{Se}$ vector; in each case $\mathrm{BrSeCCC}$ are virtually 
coplanar [mean deviation L2a 0.0195(1) ̊; L2b 0.0321(1) ̊] with the silver atom sitting in the peri-gap, displaced L2a 2.286(1) $\AA$ and L2b 2.391(1) $\AA$ above this plane, with the Ag-BrSe plane inclined by $\mathbf{L 2 a} 105.55(1)^{\circ}$ and L2b $100.66(1)^{\circ}$ (Figure 5 12). Within the extended structure, weak intermolecular $\mathrm{CH} \cdots \pi$, $\mathrm{CF} \cdots \pi, \mathrm{CH} \cdots \mathrm{F}$ and $\mathrm{CH} \cdots \mathrm{O}$ interactions link neighbouring triflate anions and acenaphthene rings to form extended chains which propagate along the $y$-axis (Figure 13).

${ }_{10}[\operatorname{AgOTf}(\mathbf{L 3})]$ 6. In stark contrast to the previous complexes, selfassembly of tellurium donor $[\mathrm{Acenap}(\mathrm{Br})(\mathrm{TePh})] \mathbf{L 3}^{20}$ with AgOTf afforded a mononuclear 1D extended helical chain polymer $\left[\mathrm{Ag}\left(\mathrm{CF}_{3} \mathrm{SO}_{3}\right)\{\mathrm{Acenap}(\mathrm{Br})(\mathrm{TePh})\}\right]_{n} \quad 6 \quad$ (Figure 14). Crystals suitable for $\mathrm{X}$-ray diffraction were obtained by slow 15 diffusion of hexane into a saturated solution of 6 in tetrahydrofuran, at room temperature in the absence of light. The asymmetric unit contains eight silver(I) centres, eight tellurium L3 ligands and eight coordinating triflate counter-anions.

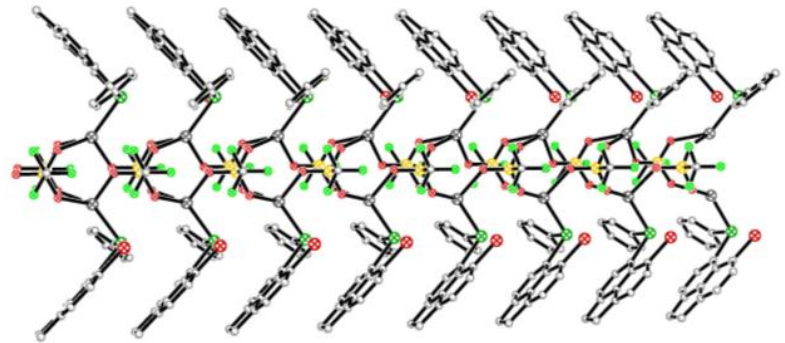

20 Fig. 14 View of the 1D extended helical chain polymer 6 along the x-axis ( $\mathrm{H}$ atoms omitted for clarity)

Within the polymeric chain, the monodentate $\mathbf{L 3}$ ligand adopts a similar coordination mode to complexes 1-5, binding through tellurium to a single silver centre $[\mathrm{Ag}(1)-\mathrm{Te}(1) 2.6714(15) \AA$;

${ }_{25}$ Figure 15]. The simultaneous coordination of four triflate molecules around each silver atom blocks any secondary coordination by additional molecules of $\mathbf{L 3}$.

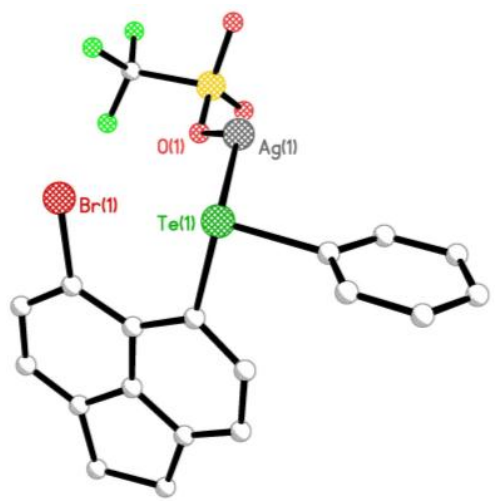

Fig. 15 The repeating unit of extended helical chain polymer 6 (H atoms 30 omitted for clarity)

In the primary coordination sphere, each silver atom coordinates with a single Te atom of an $\mathbf{L 3}$ ligand and an $\mathrm{O}$ atom from the closest triflate anion, thus adopting a distorted bent geometry $\left[\mathrm{Ag}(1)-\mathrm{O}(1)\right.$ 2.377(9) $\AA$; $\mathrm{Te}(1)-\mathrm{Ag}(1)-\mathrm{O}(1)$ 135.04(19) ${ }^{\circ}$; Figure 35 15]. Three supplementary weak Ag $\cdots O$ interactions link the silver ion to three separate triflate anions generating a distorted see-saw geometry $\left[\operatorname{Ag}(1) \cdots \mathrm{O}(2)^{2} 2.469(9) \AA \circ \quad \operatorname{Ag}(1) \cdots \mathrm{O}(3)^{1}\right.$ $\left.2.778(10) \AA ; \operatorname{Ag}(1) \cdots O(3)^{3} 2.518(9) \AA\right]$. Subsequently each triflate molecule, binding through all three $\mathrm{O}$ atoms, acts as a ${ }_{40}$ linker between four neighbouring silver centres ( $\mu_{4}$-bridging) and helps to propagate the extended chain structure (Figure 16).

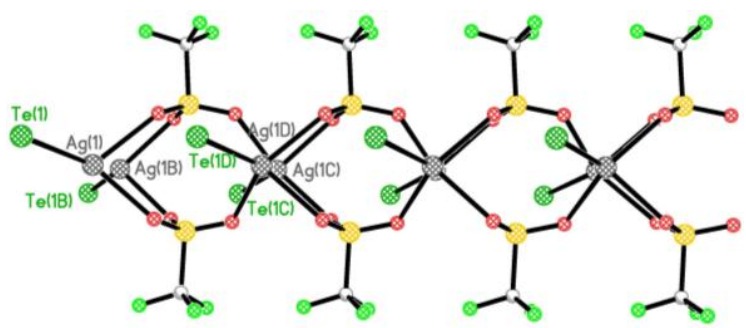

Fig. 16 The central coordination channel of 6 constructed from Ag, S and $\mathrm{O}$ atoms showing the bridging triflate anions.

${ }_{45}$ Repeating $\left(\mathrm{Ag}_{2} \mathrm{OTf}_{2} \mathbf{L} \mathbf{3}_{2}\right)_{n}$ units, connected by the network of bridging triflate anions, extend along the y-axis to form 1D chains (Figures 14, 16). The central coordination channel made up of $\mathrm{Ag}, \mathrm{S}$ and $\mathrm{O}$ atoms which dominates the extended lattice (Figure 16), is constructed around a single helical chain; silver 50 centres are linked by $\mathrm{O}-\mathrm{S}-\mathrm{O}$ bridges from identical triflate molecules to form a left-handed helix [(-Ag(1)-O(3)-S(1)-O(2)$\mathrm{Ag}(1)-\mathrm{O}(1)-\mathrm{S}(1)-\mathrm{O}(2)-\mathrm{Ag}(1)-)_{\mathrm{n}}$; Figure 17]. Additionally, as a consequence of the symmetry, each $\mathrm{Ag}_{2} \mathrm{OTf}_{2} \mathbf{L} \mathbf{3}_{2}$ unit combines to form symmetrical 8-membered macrocycles $\left(\mathrm{Ag}_{2} \mathrm{~S}_{2} \mathrm{O}_{4}\right)$ which 55 stack along the direction of the coordination channel.

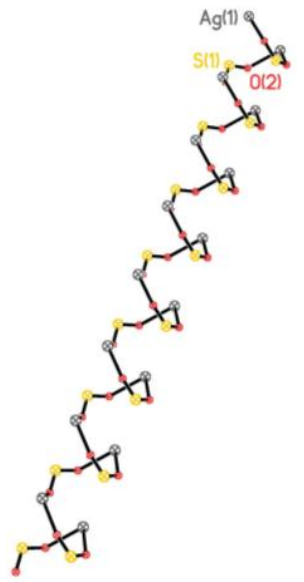

Fig. 17 The left-handed helix [(-Ag(1)-O(3)-S(1)-O(2)-Ag(1)-O(1)-S(1)$\left.\mathrm{O}(2)-\mathrm{Ag}(1)-)_{n}\right]$ running through polymeric chain 6

Extra stabilisation within each helical chain is provided by a 60 number of weak intermolecular interactions; neighbouring acenaphthene fragments are connected by $\mathrm{CH} \cdots \pi$ and $\mathrm{CBr} \cdots \pi$ interactions whilst short $\mathrm{CH} \cdots \mathrm{O}$ and $\mathrm{CH} \cdots \mathrm{F}$ contacts link triflate anions to the organic backbone. Neighbouring helical chains extend parallel along the y-axis (Figure 18) and are connected by ${ }_{65}$ weak $\mathrm{CH} \cdots \pi$ bonds between neighbouring acenaphthene fragments.

Looking down the extended chain polymer, the silver(I) ions align in two columns with the closest Ag $\cdots$ Ag distance 3.542(1) $70 \AA$, slightly longer than twice the van der Waals radii of silver $(3.44 \AA) .{ }^{24}$ Unsurprisingly the geometry of the acenaphthene fragment in $\mathbf{6}$ is unaffected by coordination within the helical chain. The equatorial arrangement positions the $\mathrm{Te}-\mathrm{C}_{\mathrm{Ph}}$ bond 
close to the acenaphthene plane, ${ }^{25}$ with no apparent change in the molecular distortion compared with the free ligand L3

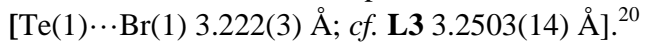

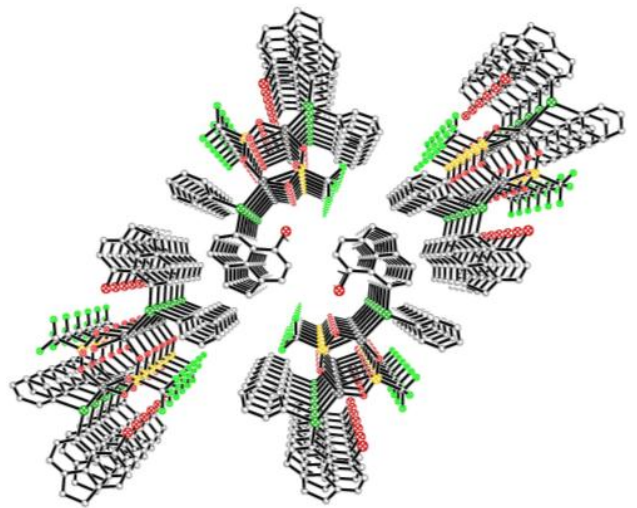

5 Fig. 18 View of the 1D extended helical chain polymer 6 along the y-axis ( $\mathrm{H}$ atoms omitted for clarity).

\section{Experimental Section}

All experiments were carried out under an oxygen- and moisturefree nitrogen atmosphere using standard Schlenk techniques and 10 glassware. Reagents were obtained from commercial sources and used as received. Dry solvents were collected from a MBraun solvent system. Elemental analyses were performed by Stephen Boyer at the London Metropolitan University. Infra-red spectra were recorded as $\mathrm{KBr}$ discs in the range $4000-300 \mathrm{~cm}^{-1}$ on a ${ }_{15}$ Perkin-Elmer System 2000 Fourier transform spectrometer. ${ }^{1} \mathrm{H}$ and ${ }^{13} \mathrm{C}$ NMR spectra were recorded on a Jeol GSX $270 \mathrm{MHz}$ spectrometer with $\delta(\mathrm{H})$ and $\delta(\mathrm{C})$ referenced to external tetramethylsilane. ${ }^{77} \mathrm{Se}$ and ${ }^{125} \mathrm{Te}$ NMR spectra were recorded on a Jeol GSX $270 \mathrm{MHz}$ spectrometer with $\delta(\mathrm{Se})$ and $\delta(\mathrm{Te})$ 20 referenced to external dimethylselenide and diphenyl ditelluride respectively. ${ }^{19} \mathrm{~F}$ NMR spectra were recorded on a Bruker Oxford $300 \mathrm{MHz}$ spectrometer with $\delta(\mathrm{F})$ referenced to external trichlorofluoromethane. Assignments of ${ }^{13} \mathrm{C}$ and ${ }^{1} \mathrm{H}$ NMR spectra were made with the help of H-H COSY and HSQC experiments.

${ }_{25}$ All measurements were performed at $25{ }^{\circ} \mathrm{C}$. All values reported for NMR spectroscopy are in parts per million (ppm). Coupling constants $(J)$ are given in Hertz $(\mathrm{Hz})$. Mass spectrometry was performed for 1, $\mathbf{2}$ and $\mathbf{4}$ by the University of St. Andrews Mass Spectrometry Service; Electrospray Mass Spectrometry (ESMS) 30 was carried out on a Micromass LCT orthogonal accelerator time of flight mass spectrometer. Mass spectrometry was performed for 3, 5 and $\mathbf{6}$ by the EPSRC National Mass Spectrometry Service in Swansea.

$35\left[\operatorname{AgBF}_{\mathbf{4}}\left\{\mathbf{A c e n a p B r}_{\mathbf{S P h}}\right\}_{\mathbf{2}}\right] \quad(\mathbf{1})$ : To a solution of silver tetrafluoroborate $(0.18 \mathrm{~g}, 0.92 \mathrm{mmol})$ in dichloromethane $(10$ $\mathrm{mL}$ ) was added a dichloromethane solution $(20 \mathrm{~mL})$ of 5-bromo6-(phenylsulfanyl)acenaphthene $(0.31 \mathrm{~g}, 0.92 \mathrm{mmol})$ at $-30{ }^{\circ} \mathrm{C}$. The reaction mixture was stirred at this temperature for $3 \mathrm{~h}$ and 40 then at room temperature for a further $12 \mathrm{~h}$ affording a cloudy solution. The crude product was collected by filtration. An analytically pure sample was obtained by recrystallization from diffusion of hexane into a saturated dichloromethane solution of the product in the absence of light $(0.19 \mathrm{~g}, 47 \%)$; mp $155-157^{\circ} \mathrm{C}$ 45 (decomp); elemental analysis (Found C, 49.3; H, 2.9. Calc. for
$\mathrm{C}_{36} \mathrm{H}_{26} \mathrm{AgBBr}_{2} \mathrm{~F}_{4} \mathrm{~S}_{2}: \mathrm{C}, 49.4 ; \mathrm{H}, 3.0 \%$ ); IR (KBr disk): $v_{\max } \mathrm{cm}^{-1}$ : $3407 \mathrm{w}, 3059 \mathrm{w}, 2922 \mathrm{w}, 2827 \mathrm{w}, 1871 \mathrm{w}, 1802 \mathrm{w}, 1743 \mathrm{w}, 1695 \mathrm{w}$, $1655 \mathrm{w}, 1598 \mathrm{~s}, 1577 \mathrm{~s}, 1478 \mathrm{~s}, 1439 \mathrm{~s}, 1417 \mathrm{~s}, 1404 \mathrm{~s}, 1320 \mathrm{~s}, 1258 \mathrm{~s}$, $1231 \mathrm{~s}, 1204 \mathrm{~s}, 1185 \mathrm{w}, 1132 \mathrm{vs}, 1085 \mathrm{vs}, 1025 \mathrm{vs}, 935 \mathrm{~s}, 854 \mathrm{~s}, 840 \mathrm{~s}$, ${ }_{50} 813 \mathrm{~s}, 765 \mathrm{w}, 750 \mathrm{vs}, 734 \mathrm{~s}, 687 \mathrm{~s}, 623 \mathrm{~s}, 605 \mathrm{~s}, 560 \mathrm{w}, 519 \mathrm{~s}, 507 \mathrm{~s}$, $467 \mathrm{~s}, 398 \mathrm{w}, 356 \mathrm{w}, 310 \mathrm{w} ; \delta_{\mathrm{H}}\left(270 \mathrm{MHz},\left(\mathrm{CD}_{3}\right)_{2} \mathrm{CO}, 25^{\circ} \mathrm{C}, \mathrm{Me}_{4} \mathrm{Si}\right)$ $7.80\left(2 \mathrm{H}, \mathrm{d},{ }^{3} J_{\mathrm{HH}} 7.4,2\right.$ x Acenap 4-H), $7.68\left(2 \mathrm{H}, \mathrm{d},{ }^{3} J_{\mathrm{HH}} 7.3,2\right.$ x Acenap 7-H), 7.40-7.16 (14 H, m, 2 x Acenap 3,8-H, 2 x SPh 12-16-H), 3.44-3.29 (8 H, m, 4 x CH$) ; \delta_{\mathrm{C}}\left(67.9 \mathrm{MHz},\left(\mathrm{CD}_{3}\right)_{2} \mathrm{CO}\right.$, $\left.{ }_{55} 25^{\circ} \mathrm{C}, \mathrm{Me}_{4} \mathrm{Si}\right)$ 151.1(q), 149.1(q), 143.2(q), 139.5(s), 138.3(q), 137.1(s), 130.8(s), 130.7(q), 128.4(s), 125.9(q), 122.8(s), 122.2(s), 114.7(q), 31.2(s, $\left.2 \times \mathrm{CH}_{2}\right), 31.0\left(\mathrm{~s}, 2 \times \mathrm{CH}_{2}\right) ; \delta_{\mathrm{F}}(376.5$ $\left.\mathrm{MHz},\left(\mathrm{CD}_{3}\right)_{2} \mathrm{CO}, 25{ }^{\circ} \mathrm{C}, \mathrm{CCl}_{3} \mathrm{~F}\right)-152.1\left(\mathrm{br} \mathrm{s},{ }^{10} \mathrm{BF}_{4}^{-}\right),-152.2$ (br s, $\left.{ }^{11} \mathrm{BF}_{4}^{-}\right)$; $\mathrm{MS}\left(\mathrm{ES}^{+}\right): \mathrm{m} / z, 790.63\left(\mathrm{M}^{+}-\mathrm{BF}_{4}^{-}, 100 \%\right)$.

60

[AgBF 4 \{AcenapBr(SePh) $\left.\}_{2}\right]$ (2): To a solution of silver tetrafluoroborate $(0.13 \mathrm{~g}, 0.65 \mathrm{mmol})$ in dichloromethane $(20$ $\mathrm{mL})$ was added 5-bromo-6-(phenylselanyl)acenaphthene $(0.25 \mathrm{~g}$, $0.65 \mathrm{mmol})$ in one batch at $-30{ }^{\circ} \mathrm{C}$. The reaction mixture was 65 stirred at this temperature for $3 \mathrm{~h}$ and then at room temperature for a further $12 \mathrm{~h}$. The solvent was removed in vacuo affording a white precipitate. An analytically pure sample was obtained by recrystallization from diffusion of hexane into a saturated acetone solution of the product in the absence of light $(0.26 \mathrm{~g}, 82 \%)$; mp 70 145-147 ${ }^{\circ} \mathrm{C}$ (decomp); elemental analysis (Found C, 44.5; H, 2.6. Calc. for $\mathrm{C}_{36} \mathrm{H}_{26} \mathrm{AgBBr}_{2} \mathrm{~F}_{4} \mathrm{Se}_{2}$ : C, 44.5; H, $2.7 \%$ ); IR (KBr disk): $v_{\max } \mathrm{cm}^{-1}: 3420 \mathrm{w}, 3048 \mathrm{w}, 2923 \mathrm{w}, 2831 \mathrm{w}, 2143 \mathrm{w}, 1874 \mathrm{w}, 1849 \mathrm{w}$, $1653 \mathrm{w}, 1599 \mathrm{~s}, 1575 \mathrm{w}, 1561 \mathrm{~s}, 1474 \mathrm{~s}, 1436 \mathrm{~s}, 1414 \mathrm{~s}, 1347 \mathrm{w}$, $1324 \mathrm{~s}, 1301 \mathrm{w}, 1255 \mathrm{w}, 1231 \mathrm{~s}, 1211 \mathrm{w}, 1082 \mathrm{vs}, 1054 \mathrm{vs}, 837 \mathrm{vs}$, $75810 \mathrm{~s}, 742 \mathrm{vs}, 686 \mathrm{~s}, 597 \mathrm{w}, 533 \mathrm{w}, 519 \mathrm{~s}, 472 \mathrm{~s}, 311 \mathrm{w} ; \delta_{\mathrm{H}}(270 \mathrm{MHz}$, $\left.\left(\mathrm{CD}_{3}\right)_{2} \mathrm{CO}, 25^{\circ} \mathrm{C}, \mathrm{Me}_{4} \mathrm{Si}\right) 7.75\left(2 \mathrm{H}, \mathrm{d},{ }^{3} J_{\mathrm{HH}} 7.4,2\right.$ x Acenap 4-H), 7.66-7.55 (4 H, m, 2 x SePh 12,16-H), 7.53-7.36 (6 H, m, 2 x $\mathrm{Se} P h$ 13-15-H), 7.24-7.12 (4 H, m, 2 x Acenap 3,7-H), 7.07 (2 H, $\mathrm{d},{ }^{3} J_{\mathrm{HH}} 7.3,2 \times$ Acenap 8-H), 3.36-3.20 (8 H, m, 4 x CH $\mathrm{CH}_{2}$ ); ${ }_{80} \delta_{\mathrm{C}}\left(67.9 \mathrm{MHz},\left(\mathrm{CD}_{3}\right)_{2} \mathrm{CO}, 25{ }^{\circ} \mathrm{C}, \mathrm{Me}_{4} \mathrm{Si}\right) 147.8(\mathrm{q}), 147.5(\mathrm{q})$, 142.0(q), 135.6(s), 134.8(s), 133.3(s), 130.3(s), 129.9(q), 129.5(q), 129.4(s), 124.1(q), 121.4(s), 121.2(s), 114.2(q), 29.9(s, $\left.2 \times \mathrm{CH}_{2}\right), 29.8\left(\mathrm{~s}, 2 \times \mathrm{CH}_{2}\right) ; \delta_{\mathrm{Se}}\left(51.5 \mathrm{MHz},\left(\mathrm{CD}_{3}\right)_{2} \mathrm{CO}, 2{ }^{\circ} \mathrm{C}\right.$, $\mathrm{PhSeSePh}) 390.6(\mathrm{~s}) ; \delta_{\mathrm{F}}\left(376.5 \mathrm{MHz},\left(\mathrm{CD}_{3}\right)_{2} \mathrm{CO}, 25^{\circ} \mathrm{C}, \mathrm{CCl}_{3} \mathrm{~F}\right)-$ ${ }_{85} 152.1$ (br s, $\left.{ }^{10} \mathrm{BF}_{4}^{-}\right),-152.2$ (br s, $\left.{ }^{11} \mathrm{BF}_{4}^{-}\right)$; $\mathrm{MS}\left(\mathrm{ES}^{+}\right): \mathrm{m} / z 884.94$ $\left(\mathrm{M}^{+}-\mathrm{BF}_{4}^{-}, 100 \%\right)$.

$\left[\operatorname{AgBF}_{4}\{\operatorname{Acenap}(\mathbf{B r})(\mathrm{TePh})\}_{2}\right]$ (3): To a solution of silver tetrafluoroborate $(0.08 \mathrm{~g}, 0.39 \mathrm{mmol})$ in dichloromethane $(20$ $90 \mathrm{~mL}$ ) was added 5-bromo-6-(phenyltelluro)acenaphthene $(0.17 \mathrm{~g}$, $0.39 \mathrm{mmol})$ in one batch at $-30{ }^{\circ} \mathrm{C}$. The reaction mixture was stirred at this temperature for $3 \mathrm{~h}$ and then at room temperature for a further $12 \mathrm{~h}$. The solvent was removed in vacuo affording a white precipitate. An analytically pure sample was obtained by 95 recrystallization from diffusion of hexane into a saturated dichloromethane solution of the product in the absence of light (0.17 g, 82\%); mp 205-207 ${ }^{\circ} \mathrm{C}$ (decomp); elemental analysis (Found C, 40.3; H, 2.5. Calc. for $\mathrm{C}_{36} \mathrm{H}_{26} \mathrm{AgBBr}_{2} \mathrm{~F}_{4} \mathrm{Te}_{2}$ : C, 40.5; $\mathrm{H}, 2.5 \%)$; IR (KBr disk): $v_{\max } \mathrm{cm}^{-1}: 3422 \mathrm{w}, 3051 \mathrm{w}, 2923 \mathrm{w}$, $1002829 \mathrm{w}, 1875 \mathrm{w}, 1811 \mathrm{w}, 1648 \mathrm{w}, 1595 \mathrm{~s}, 1558 \mathrm{w}, 1474 \mathrm{w}, 1435 \mathrm{~s}$, $1417 \mathrm{~s}, 1325 \mathrm{~s}, 1284 \mathrm{w}, 1256 \mathrm{w}, 1230 \mathrm{w}, 1212 \mathrm{w}, 1078 \mathrm{vs}, 1053 \mathrm{vs}$, $1011 \mathrm{vs}, 839 \mathrm{~s}, 809 \mathrm{~s}, 764 \mathrm{w}, 742 \mathrm{vs}, 686 \mathrm{~s}, 630 \mathrm{~s}, 595 \mathrm{w}, 536 \mathrm{w}$, 519w, 493w, 454w, 354w; $\delta_{\mathrm{H}}\left(270 \mathrm{MHz},\left(\mathrm{CD}_{3}\right)_{2} \mathrm{CO}, 25{ }^{\circ} \mathrm{C}\right.$, 
$\left.\mathrm{Me}_{4} \mathrm{Si}\right)$ 8.02-7.91 (2 H, m, TePh 12,16-H), $7.71\left(1 \mathrm{H}, \mathrm{d},{ }^{3} J_{\mathrm{HH}} 7.5\right.$, Acenap 4-H), 7.62-7.45 (1 H, m, TePh 14-H), 7.45-7.34 (2 H, m, TePh 13,15-H), 7.20 (1 H, d, ${ }^{3} J_{\mathrm{HH}} 7.5$, Acenap 3-H), $7.16(1 \mathrm{H}, \mathrm{d}$, ${ }^{3} J_{\mathrm{HH}} 7.6$, Acenap 7-H), $7.02\left(1 \mathrm{H}, \mathrm{d},{ }^{3} J_{\mathrm{HH}} 7.6\right.$, Acenap 8-H), 3.28$53.17\left(4 \mathrm{H}, \mathrm{m}, 2 \times \mathrm{CH}_{2}\right) ; \delta_{\mathrm{C}}\left(67.9 \mathrm{MHz},\left(\mathrm{CD}_{3}\right)_{2} \mathrm{CO}, 25^{\circ} \mathrm{C}, \mathrm{Me}_{4} \mathrm{Si}\right)$ 142.0(s), 137.9(s), 133.4(s), 132.1(s), 131.9(s), 123.1(s), 123.0(s), 29.6(s, $\left.\mathrm{CH}_{2}\right), 29.3\left(\mathrm{~s}, \mathrm{CH}_{2}\right) ; \delta_{\mathrm{Te}}\left(81.2 \mathrm{MHz},\left(\mathrm{CD}_{3}\right)_{2} \mathrm{CO}, 25^{\circ} \mathrm{C}\right.$, $\mathrm{PhTeTePh}) 562.0(\mathrm{~s}) ; \delta_{\mathrm{F}}\left(376.5 \mathrm{MHz},\left(\mathrm{CD}_{3}\right)_{2} \mathrm{CO}, 25^{\circ} \mathrm{C}, \mathrm{CCl}_{3} \mathrm{~F}\right)-$ 152.1(br s, $\left.{ }^{10} \mathrm{BF}_{4}^{-}\right),-152.2$ (br s, $\left.{ }^{11} \mathrm{BF}_{4}^{-}\right)$; $\mathrm{MS}\left(\mathrm{ES}^{+}\right): \mathrm{m} / z, 982.75$ $10\left(\mathrm{M}^{+}-\mathrm{BF}_{4}^{-}, 100 \%\right)$.

$\left[\mathrm{AgCF}_{3} \mathrm{SO}_{3}\{\mathrm{AcenapBr}(\mathrm{SPh})\}_{3}\right]$ (4): To a solution of silver trifluoromethanesulfonate $(0.21 \mathrm{~g}, \quad 0.81 \quad \mathrm{mmol}) \quad$ in dichloromethane $(10 \mathrm{~mL})$ was added a dichloromethane solution $15(20 \mathrm{~mL})$ of 5-bromo-6-(phenylsulfanyl)acenaphthene $(0.28 \mathrm{~g}$, $0.81 \mathrm{mmol})$ at $-30{ }^{\circ} \mathrm{C}$. The reaction mixture was stirred at this temperature for $3 \mathrm{~h}$ and then at room temperature for a further 12 $\mathrm{h}$ affording a cloudy solution. The crude product was collected by filtration. An analytically pure sample was obtained by 20 recrystallization from diffusion of hexane into a saturated dichloromethane solution of the product in the absence of light (0.32 g, 92\%); mp 165-167 ${ }^{\circ} \mathrm{C}$ (decomp); IR (KBr disk): $v_{\max } \mathrm{cm}^{-}$ ${ }^{1}$ : 3442w, 3071w, 3054w, 3005w, 2927w, 2882w, 2835w, 2432w, 2346w, 2259w, 2202w, 1936w, 1873w, 1789w, 1729w, 1669w, $251639 \mathrm{w}, 1598 \mathrm{~s}, 1580 \mathrm{~s}, 1479 \mathrm{~s}, 1439 \mathrm{~s}, 1409 \mathrm{~s}, 1323 \mathrm{vs}, 1264 \mathrm{vs}$, $1172 \mathrm{vs}, 1114 \mathrm{~s}, 1079 \mathrm{~s}, 1028 \mathrm{vs}, 899 \mathrm{~s}, 864 \mathrm{~s}, 844 \mathrm{vs}, 815 \mathrm{~s}, 763 \mathrm{w}$, 735vs, 688s, 633vs, 577s, 517vs, 493s, 469s, 409w, 349w, 323w; $\delta_{\mathrm{H}}\left(270 \mathrm{MHz},\left(\mathrm{CD}_{3}\right)_{2} \mathrm{CO}, 25^{\circ} \mathrm{C}, \mathrm{Me}_{4} \mathrm{Si}\right) 7.79\left(3 \mathrm{H}, \mathrm{d},{ }^{3} J_{\mathrm{HH}} 7.4,3 \mathrm{x}\right.$ Acenap 4-H), $7.65\left(3 \mathrm{H}, \mathrm{d},{ }^{3} J_{\mathrm{HH}} 7.3,3\right.$ x Acenap 7-H), 7.36-7.17 30 (15 H, m, 3 x Acenap 3,8-H, 3 x SPh 13-15-H), 7.17-7.07 (6 H, $\mathrm{m}, 3 \times \mathrm{SPh} 12,16-\mathrm{H}), 3.44-3.30\left(12 \mathrm{H}, \mathrm{m}, 6 \times \mathrm{CH}_{2}\right) ; \delta_{\mathrm{C}}(67.9$ $\left.\mathrm{MHz},\left(\mathrm{CD}_{3}\right)_{2} \mathrm{CO}, 25{ }^{\circ} \mathrm{C}, \mathrm{Me}_{4} \mathrm{Si}\right)$ 149.3(q), 147.8(q), 142.0(q), 139.0(q), 138.5(s), 135.8(s), 129.9(q), 129.4(s), 128.9(s), 126.3(s), 125.7(q), 121.4(s), 120.9(s), 113.8(q), 30.0(s, $3 \times \mathrm{CH}_{2}$ ), $3529.8\left(\mathrm{~s}, 3 \times \mathrm{CH}_{2}\right) ; \delta_{\mathrm{F}}\left(376.5 \mathrm{MHz},\left(\mathrm{CD}_{3}\right)_{2} \mathrm{CO}, 25^{\circ} \mathrm{C}, \mathrm{CCl}_{3} \mathrm{~F}\right)-$ 79.3(s); MS $\left(\mathrm{ES}^{+}\right): \mathrm{m} / \mathrm{z}, 1302.73\left(\mathrm{M}^{+}+\mathrm{Na}, 5 \%\right), 1046.8\left(\mathrm{M}^{+}+\mathrm{Na}-\right.$ AgOTf, 15), $788.76\left(\mathrm{M}^{+}-\{\right.$Acenap(Br)(SPh)(OTf)\}, 100).

$\left[\mathrm{AgCF}_{3} \mathrm{SO}_{3}\{\operatorname{AcenapBr}(\mathrm{SePh})\}_{2}\right]$ (5): To a solution of silver 40 trifluoromethanesulfonate $(0.14 \quad \mathrm{~g}, \quad 0.70 \quad \mathrm{mmol})$ in dichloromethane $(10 \mathrm{~mL})$ was added a dichloromethane solution (20 mL) of 5-bromo-6-(phenylselanyl)acenaphthene $(0.27 \mathrm{~g}, 0.70$ mmol) at $-30{ }^{\circ} \mathrm{C}$. The reaction mixture was stirred at this temperature for $3 \mathrm{~h}$ and then at room temperature for a further 12 $45 \mathrm{~h}$. The reaction mixture was filtered and the solvent was removed in vacuo affording a brown precipitate. An analytically pure sample was obtained by recrystallization from diffusion of hexane into a saturated acetone solution of the product in the absence of light $(0.22 \mathrm{~g}, 61 \%)$; mp $130-132{ }^{\circ} \mathrm{C}$ (decomp); 50 elemental analysis (Found $\mathrm{C}, 42.9 ; \mathrm{H}$, 2.4. Calc. for $\mathrm{C}_{37} \mathrm{H}_{26} \mathrm{AgBr}_{2} \mathrm{~F}_{3} \mathrm{O}_{3} \mathrm{SSe}_{2}$ : C, 43.0; H, $2.5 \%$ ); IR ( $\mathrm{KBr}$ disk): $v_{\text {max }}$ $\mathrm{cm}^{-1}$ : 3423w, 3069w, 2929w, 2833w, 2231w, 1952w, 1858w, $1749 \mathrm{w}, 1652 \mathrm{w}, 1597 \mathrm{~s}, 1575 \mathrm{w}, 1561 \mathrm{~s}, 1473 \mathrm{w}, 1437 \mathrm{~s}, 1411 \mathrm{~s}$, $1348 \mathrm{w}, 1327 \mathrm{~s}, 1291 \mathrm{vs}, 1254 \mathrm{vs}, 1234 \mathrm{vs}, 1215 \mathrm{vs}, 1158 \mathrm{vs}, 1108 \mathrm{~s}$, $551065 \mathrm{w}, 1019 \mathrm{vs}, 935 \mathrm{w}, 912 \mathrm{w}, 837 \mathrm{vs}, 810 \mathrm{~s}, 739 \mathrm{vs}, 687 \mathrm{~s}, 633 \mathrm{vs}$, $601 \mathrm{~s}, 570 \mathrm{w}, 514 \mathrm{~s}, 472 \mathrm{w}, 356 \mathrm{w}, 312 \mathrm{w} ; \delta_{\mathrm{H}}\left(270 \mathrm{MHz},\left(\mathrm{CD}_{3}\right)_{2} \mathrm{CO}\right.$, $\left.25^{\circ} \mathrm{C}, \mathrm{Me}_{4} \mathrm{Si}\right) 7.62\left(2 \mathrm{H}, \mathrm{d},{ }^{3} J_{\mathrm{HH}} 7.4,2\right.$ x Acenap 4-H), 7.60-7.51 (4 H, m, 2 x SePh 12,16-H), 7.43-7.27 (6 H, m, 2 x SePh 13-15-
H), 7.15-7.03 (4 H, m, 2 x Acenap 3,7-H), $6.98\left(2 \mathrm{H}, \mathrm{d},{ }^{3} J_{\mathrm{HH}} 7.4\right.$, 602 x Acenap 8-H), 3.20-3.11 (8 H, m, 4 x CH$) ; \delta_{\mathrm{H}}(67.9 \mathrm{MHz}$, $\left.\left(\mathrm{CD}_{3}\right)_{2} \mathrm{CO}, 25^{\circ} \mathrm{C}, \mathrm{Me}_{4} \mathrm{Si}\right) 149.0(\mathrm{q}), 148.9(\mathrm{q}), 143.2(\mathrm{q}), 137.4(\mathrm{q})$, 136.9(s), 136.0(s), 134.7(s), 131.5(s), 130.9(q), 130.8(s), 122.6(s), 122.4(s), 115.6(q), 115.3(q), 29.3(s, $\left.2 \times \mathrm{CH}_{2}\right), 29.0(\mathrm{~s}, 2$ x $\left.\mathrm{CH}_{2}\right) ; \delta_{\mathrm{Se}}\left(51.5 \mathrm{MHz},\left(\mathrm{CD}_{3}\right)_{2} \mathrm{CO}, 25^{\circ} \mathrm{C}, \mathrm{PhSeSePh}\right) 387.8(\mathrm{~s})$; ${ }_{65} \delta_{\mathrm{F}}\left(376.5 \mathrm{MHz},\left(\mathrm{CD}_{3}\right)_{2} \mathrm{CO}, 25^{\circ} \mathrm{C}, \mathrm{CCl}_{3} \mathrm{~F}\right)-79.2(\mathrm{~s}) ; \mathrm{MS}\left(\mathrm{ES}^{+}\right): \mathrm{m} / \mathrm{z}$ $884.77\left(\mathrm{M}^{+}\right.$-OTf, $\left.100 \%\right)$.

$\left[\mathrm{AgCF}_{3} \mathrm{SO}_{3}\{\operatorname{Acenap}(\mathrm{Br})(\mathrm{TePh})\}\right]$ (6): To a solution of silver trifluoromethanesulfonate $(0.11 \quad \mathrm{~g}, \quad 0.44 \quad \mathrm{mmol}) \quad$ in 70 dichloromethane $(10 \mathrm{~mL})$ was added a dichloromethane solution $(20 \mathrm{~mL})$ of 5-bromo-6-(phenyltelluro)acenaphthene $(0.19 \mathrm{~g}, 0.44$ mmol) at $-30{ }^{\circ} \mathrm{C}$. The reaction mixture was stirred at this temperature for $3 \mathrm{~h}$ and then at room temperature for a further 12 $\mathrm{h}$ affording a cloudy solution. The crude product was collected by 75 filtration. An analytically pure sample was obtained by recrystallization from diffusion of hexane into a saturated tetrahydrofuran solution of the product in the absence of light (0.28 g, 92\%); mp 158-160 ${ }^{\circ} \mathrm{C}$ (decomp); elemental analysis (Found C, 32.9; H, 1.9. Calc. for $\mathrm{C}_{19} \mathrm{H}_{13} \mathrm{AgBrF}_{3} \mathrm{O}_{3} \mathrm{STe}$ : C, 32.9; ${ }_{80} \mathrm{H}, 1.9 \%$ ); IR (KBr disk): $v_{\max } \mathrm{cm}^{-1}: 1332 \mathrm{w}, 1249 \mathrm{vs}, 1225 \mathrm{vs}$, 1176vs, 1106s, 1064w, 1031vs, 994s, 913w, 842s, 815s, 765w, 733s, 689s, 633vs, 600w, 579s, 517vs, 467w, 452w, 420w, 398w, $354 \mathrm{w}, 323 \mathrm{w} ; \delta_{\mathrm{H}}\left(270 \mathrm{MHz}, \mathrm{CD}_{3} \mathrm{CN}, 25^{\circ} \mathrm{C}, \mathrm{Me}_{4} \mathrm{Si}\right) 7.92-7.78(2$ $\mathrm{H}, \mathrm{m}, \mathrm{Te} P h$ 12,16-H), 7.69 (1 H, d, ${ }^{3} J_{\mathrm{HH}} 7.4$, Acenap 4-H), 7.62857.51 (1 H, m, TePh 14-H), 7.48-7.34 (2 H, m, TePh 13,15-H), $7.16\left(1 \mathrm{H}, \mathrm{d},{ }^{3} J_{\mathrm{HH}}=7.4\right.$, Acenap 3-H), $7.07\left(1 \mathrm{H}, \mathrm{d},{ }^{3} J_{\mathrm{HH}}=7.4\right.$, Acenap 7-H), 6.94 (1 H, d, ${ }^{3} J_{\mathrm{HH}}$ 7.4, Acenap 8-H), 3.34-3.15 (4 $\left.\mathrm{H}, \mathrm{m}, 2 \times \mathrm{CH}_{2}\right) ; \delta_{\mathrm{C}}\left(67.9 \mathrm{MHz}, \mathrm{CD}_{3} \mathrm{CN}, 25^{\circ} \mathrm{C}, \mathrm{Me}_{4} \mathrm{Si}\right) 148.2(\mathrm{q})$, 148.0(q), $141.6(\mathrm{q}), \quad 140.0(\mathrm{~s}), \quad 135.6(\mathrm{~s}), \quad 133.6(\mathrm{~s}), \quad 130.9(\mathrm{q})$, $90130.2(\mathrm{~s}), \quad 130.0(\mathrm{~s}), \quad 122.9(\mathrm{q}), \quad 121.2(\mathrm{~s}), \quad 121.0(\mathrm{~s}), \quad 114.9(\mathrm{q})$, 106.9(q), 29.2(s, $\left.\mathrm{CH}_{2}\right), 29.1\left(\mathrm{~s}, \mathrm{CH}_{2}\right) ; \delta_{\mathrm{Te}}\left(81.2 \mathrm{MHz}, \mathrm{CD}_{3} \mathrm{CN}, 25\right.$ $\left.{ }^{\circ} \mathrm{C}, \mathrm{PhTeTePh}\right) 559.0(\mathrm{~s}) ; \delta_{\mathrm{F}}\left(376.5 \mathrm{MHz}, \mathrm{CD}_{3} \mathrm{CN}, 25^{\circ} \mathrm{C}, \mathrm{CCl}_{3} \mathrm{~F}\right)-$ 79.7(s); MS (ES $\left.{ }^{+}\right): m / z, 544.8\left(\mathrm{M}^{+}-\mathrm{OTf}, 100 \%\right)$.

\section{Crystal structure analyses}

${ }_{95} \mathrm{X}$-ray crystal structures for 1-3 and 6 were determined at -148(1) ${ }^{\circ} \mathrm{C}$ on the St Andrews Robotic Diffractometer ${ }^{27}$ a Rigaku ACTOR-SM, Saturn 724 CCD area detector with graphite monochromated Mo-K $\alpha$ radiation $(\lambda=0.71073 \AA)$. The data was corrected for Lorentz, polarisation and absorption. Data for 100 compounds 4 and $\mathbf{5}$ were collected at $-180(1){ }^{\circ} \mathrm{C}$ by using a Rigaku MM007 High brilliance RA generator (Mo K $\alpha$ radiation, confocal optic) and Saturn CCD system. At least a full hemisphere of data was collected using $\omega$ scans. Intensities were corrected for Lorentz, polarisation and absorption. The data for 105 the complexes analysed was collected and processed using CrystalClear (Rigaku). ${ }^{28}$ The structures were solved by direct methods ${ }^{29}$ and expanded using Fourier techniques. ${ }^{30}$ The nonhydrogen atoms were refined anisotropically. Hydrogen atoms were refined using the riding model. All calculations were 110 performed using the CrystalStructure ${ }^{31}$ crystallographic software package except for refinement, which was performed using SHELXL-97. ${ }^{32}$ These X-ray data can be obtained free of charge via www.ccdc.cam.ac.uk/conts/retrieving.html or from the Cambridge Crystallographic Data centre, 12 Union Road, ${ }_{115}$ Cambridge CB2 1EZ, UK; fax (+44) 1223-336-033; e-mail: 
deposit@ccdc.cam.ac.uk CCDC Nos: .

\section{Conclusions}

The self-assembly of chalcogen-donor acenaphthenes 5 [Acenap $(\mathrm{Br})(\mathrm{EPh})]($ Acenap = acenaphthene-5,6-diyl; $\mathrm{E}=\mathrm{S}, \mathrm{Se}$, Te) $\mathbf{L 1}-\mathbf{L 3}^{20}$ with silver(I) salts, $\mathrm{AgBF}_{4}$ and AgOTf, afforded six distinct silver(I) coordination complexes 1-6, including two rare examples of organo-telluride silver(I) coordination. In each compound, the organic acenaphthene ligand (L1-L3) adopts the 10 same ligation mode, binding to silver via classical monodentate coordination through the chalcogen atom. Nevertheless, modification of the chalcogen congeners within the ligand shell and the coordinating ability of the respective counter-anion affects the geometry adopted by the silver centre (linear, bent, 15 trigonal planar, tetrahedral) and the structure of the final complex, generating two, three and four coordinate monomeric, mononuclear silver(I) complexes 1-5 and 1D polymeric chain 6 .

Independent reactions of the three chalcogen ligands L1-L3 with $20 \mathrm{AgBF}_{4}$ afforded three monomeric, mononuclear two-coordinate complexes. In each case, the $\mathrm{BF}_{4}^{-}$anion was shown to be noncoordinating, although weak intermolecular Ag $\cdots \mathrm{F}$ interactions were observed. In the sulfur derivative 1, silver adopts a bent coordination geometry, with neighbouring molecules associating 25 to form dimers centred on an $\mathrm{Ag}_{2} \mathrm{~F}_{2}$ rhombus core. Introduction of the heavier chalcogen congeners in the isomorphous complexes $\mathbf{2}$ and $\mathbf{3}$, resulted in a linear metal geometry, with additional weak $\mathrm{Ag} \cdots \mathrm{Br}$ contacts constructing a quasi-chelate ring between the ligand and the silver centre in a distorted see30 saw arrangement.

In contrast, the strong coordinating ability of the triflate anion affords two related monomeric three- (5) and four-coordinate (4) complexes and a 1D extended polymeric chain 6. In each case, 35 the triflate binds to silver via monodentate coordination through a single $\mathrm{O}$ atom, with additional weak $\mathrm{Ag} \cdots \mathrm{O}$ contacts in 6 affording a quasi-tetra-monodentate $\mu_{4}$-bridging mode. The fourcoordinate complex $\mathbf{4}$ is constructed from three sulfur L1 ligands and a single triflate molecule, generating a tetrahedral 40 environment around the central silver atom. In complex $\mathbf{5}$, the additional bulk of the selenium ligand reduces the coordination, resulting in only two $\mathbf{L 2}$ ligands and a triflate ion around the trigonal pyramidal silver. The mononuclear $1 \mathrm{D}$ polymeric chain 6 is assembled from repeating $\left(\mathrm{Ag}_{2} \mathrm{OTf}_{2} \mathbf{L} \mathbf{3}_{2}\right)_{n}$ units, linked by a 45 network of $\mu_{4}$-bridging triflate anions. The central coordination channel within the extended lattice is constructed from secondary silver-triflate interactions and contains a single left-handed helix $\left[(-\mathrm{Ag}(1)-\mathrm{O}(3)-\mathrm{S}(1)-\mathrm{O}(2)-\mathrm{Ag}(1)-\mathrm{O}(1)-\mathrm{S}(1)-\mathrm{O}(2)-\mathrm{Ag}(1)-)_{n}\right]$.

\section{${ }_{50}$ Acknowledgements}

Elemental analyses were performed Stephen Boyer at the London Metropolitan University. Mass Spectrometry was performed at the University of St. Andrews Mass Spectrometry Service by
Caroline Horsburgh and at the EPSRC National Mass ${ }_{55}$ Spectrometry Service in Swansea. The work in this project was supported by the Engineering and Physical Sciences Research Council (EPSRC).

\section{Notes and references}

${ }^{a}$ School of Chemistry, University of St Andrews, St Andrews, Fife, U.K. 60 Fax: (+44) 1334 463384; Tel: (+44)1334 463861; E-mail: jdw3@standrews.ac.uk, frk@st-andrews.ac.uk

$\dagger$ Electronic Supplementary Information (ESI) available: X-ray crystal structure data; tables and figures. See DOI: 10.1039/b000000x/

651 D. Venkataraman, Y. Du, S. R. Wilson, K. A. Hirsch, P. Zhang and J. S. Moore, J. Chem. Educ., 1997, 74, 915.

2 a) C.-T. Chen and K. S. Suslick, Coord. Chem. Rev., 1993, 128, 293; b) M. Fujita, Y. J. Kwon, S. Washizu and K. Ogura, J. Am. Chem. Soc., 1994, 116, 1151; c) B. F. Hoskins and R. Robson, J. Am. Chem. Soc., 1990, 112, 1546.

3 a) L. Carlucci, G. Ciani, D. M. Proserpio and A. Sironi, J. Am. Chem. Soc., 1995, 117, 4562; b) G. B. Gardner, D. Venkataraman, J. S. Moore and S. Lee, Nature, 1995, 374, 792.

4 a) B. Li, S.-Q. Zang, R. Liang, Y.-J. Wu and T. C. W. Mak, 75 Organometallics, 2011, 30, 1710; b) J.-R. Li, X.-He. Bu, J. Jiao, W.P. Du, X.-H. Xu and R.-H. Zhang, Dalton Trans., 2005, 464; c) C.-K. Tan, J. Wang, J.-D. Leng, L.-L. Zheng and M.-L. Tong, Eur. J. Inorg. Chem., 2008, 771.

5 a) A. D. Burrows, D. J. Kelly, M. F. Mahon, P. R. Raithby, C. 80 Richardson and A. J. Stevenson, Dalton Trans., 2011, 40, 5483; b) X.-H. Bu, W. Chen, W.-F.Hou, M. Du, R.-H. Zhang and F. Brisse, Inorg. Chem., 2002, 41, 3477; c) J.-R. Li, R.-H. Zhang and X.-H. Bu, J. Chem. Crystallogr., 2004, 34, 501.

6 C.-K. Tan, J. Wang, J.-D. Leng, L.-L. Zheng and M.-L. Tong, Eur. J. $85 \quad$ Inorg. Chem., 2008, 771.

7 D. G. Booth, W. Levason, J. J. Quirk, G. Reid and S. M. Smith, Dalton Trans., 1997, 3493.

8 A. G. Young and L. R. Hanton, Coord. Chem. Rev., 2008, 252, 1346.

9 I. Ino, L. P. Wu, M. Munakata, M. Maekawa, Y. Suenaga, T. Kuroda$90 \quad$ Sowa and Y. Kitamori, Inorg Chem., 2000, 39, 2146.

10 P. L. Caradoc-Davies and L. R. Hanton, Chem. Commun., 2001, 1098.

11 a) C. A. Coulson, R. Daudel and J. M. Robertson, Proc. R. Soc. London Ser. A., 1951, 207, 306; b) D. W. Cruickshank, Acta 95 Crystallogr., 1957, 10, 504; c) C. P. Brock and J. D. Dunitz, Acta Crystallogr., Sect. B, 1982, 38, 2218; d) J. Oddershede and S. Larsen, J. Phys. Chem. A, 2004, 108, 1057.

12 A. C. Hazell, R. G. Hazell, L. Norskov-Lauritsen, C. E. Briant and D. W. Jones, Acta Crystallogr., Sect. C, 1986, 42, 690.

10013 a) P. Kilian, F. R. Knight and J. D. Woollins, Chem. Eur. J., 2011, 17, 2302; b) P. Kilian, F. R. Knight and J. D. Woollins, Coord. Chem. Rev., 2011, 255, 1387.

14 V. Balasubramaniyan, Chem. Rev., 1966, 66, 567.

15 a) S. M. Aucott, H. L. Milton, S. D. Robertson, A. M. Z. Slawin, G. 105 D. Walker and J. D. Woollins, Chem. Eur. J., 2004, 10, 1666: b) S. M. Aucott, H. L. Milton, S. D. Robertson, A. M. Z. Slawin and J. D. Woollins, Heteroat. Chem., 2004, 15, 531; c) S. M. Aucott, H. L. Milton, S. D. Robertson, A. M. Z. Slawin and J. D. Woollins, Dalton Trans., 2004, 3347: d) S. M. Aucott, P. Kilian, H. L. Milton, S. D. 110 Robertson, A. M. Z. Slawin and J. D. Woollins, Inorg. Chem., 2005, 44, 2710; e) S. M. Aucott, P. Kilian, S. D. Robertson, A. M. Z. Slawin and J. D. Woollins, Chem. Eur. J., 2006, 12, 895: f) S. M. Aucott, D. Duerden, Y. Li, A. M. Z. Slawin, J. D. Woollins, Chem. Eur. J., 2006, 12, 5495.

11516 a) P. Kilian, A. M. Z. Slawin and J. D. Woollins, Dalton Trans., 2003, 3876; b) P. Kilian, D. Philp, A. M. Z. Slawin and J. D. Woollins, Eur. J. Inorg. Chem., 2003, 249: c) P. Kilian, A. M. Z. Slawin and J. D. Woollins, Chem. Eur. J., 2003, 9, 215; d) P. Kilian, A. M. Z. Slawin and J. D. Woollins, Chem. Commun., 2003, 1174; e) 120 P. Kilian, H. L. Milton A. M. Z. Slawin and J. D. Woollins, Inorg. Chem., 2004, 43, 2252; f) P. Kilian, A. M. Z. Slawin and J. D. 
Woollins, Inorg. Chim. Acta, 2005, 358, 1719; g) P. Kilian, A. M. Z. Slawin and J. D. Woollins, Dalton Trans., 2006, 2175.

17 a) F. R. Knight, A. L. Fuller, A. M. Z. Slawin and J. D. Woollins, Dalton Trans., 2009, 8476; b) F. R. Knight, A. L. Fuller, A. M. Z.

$5 \quad$ Slawin and J. D. Woollins, Polyhedron, 2010, 29, 1849; c) F. R. Knight, A. L. Fuller, A. M. Z. Slawin and J. D. Woollins, Polyhedron, 2010, 29, 1956; d) F. R. Knight, A. L. Fuller, M. Bühl, A. M. Z. Slawin, J. D. Woollins, Chem. Eur. J., 2010, 16, 7617.

18 a) F. R. Knight, A. L. Fuller, M. Bühl, A. M. Z. Slawin and J. D. 10 Woollins, Chem. Eur. J., 2010, 16, 7503; b) A. L. Fuller, F. R. Knight, A. M. Z. Slawin and J. D. Woollins, Eur. J. Inorg. Chem., 2010, 4034; c) F. R. Knight, A. L. Fuller, M. Bühl, A. M. Z. Slawin and J. D. Woollins, Inorg. Chem., 2010, 49, 7577; d) F. R. Knight, A. L. Fuller, M. Bühl, A. M. Z. Slawin and J. D. Woollins, Chem. Eur.

$15 \quad J ., 2010,16,7605$; e) A. L. Fuller, F. R. Knight, A. M. Z. Slawin and J. D. Woollins, Acta Crystallogr., Sect. E, 2007, E63, o3855; f) A. L. Fuller, F. R. Knight, A. M. Z. Slawin and J. D. Woollins, Acta Crystallogr., Sect. E, 2007, E63, o3957; g) A. L. Fuller, F. R. Knight, A. M. Z. Slawin and J. D. Woollins, Acta Crystallogr., Sect. E, 2008, E64, 0977.

19 M.-L. Lechner, K. S. Athukorala Arachchige, R. A. M. Randall, F. R. Knight, M. Bühl, A. M. Z. Slawin and J. D. Woollins, Organometallics, 2012, 31, 2922.

20 a) L. K. Aschenbach, F. R. Knight, R. A. M. Randall, D. B. Cordes, 25 A. Baggott, M. Bühl, A. M. Z. Slawin and J. D. Woollins, Dalton Trans., 2012, 41, 3141; b) F. R. Knight, K. S. Athukorala Arachchige, R. A. M. Randall, M. Bühl, A. M. Z. Slawin and J. D. Woollins, Dalton Trans., 2012, 41, 3154.

21 F. R. Knight, R. A. M. Randall, L. Wakefield, A. M. Z. Slawin and J. 30 D. Woollins, Inorg. Chem., 2012, submitted.

22 F. H. Allen, J. E. Davies, J. J. Galloy, O. Johnson, O. Kennard, C. F. Macrae, E. M. Mitchell, G. F. Mitchell, J. M. Smith and D. G. Watson, J. Chem. Inf. Comput. Sci., 1991, 31, 187.

23 a) W. Levason, M. Nirwan, R. Ratnani, G. Reid, N. Tsoureas and M.

35 Webster, Dalton Trans., 2007, 439; b) W. Levason, G. Reid and V.A. Tolhurst, J. Chem. Soc., Dalton Trans., 1998, 3411; c) K. Kobayashi, H. Masu, A. Shuto and K. Yamaguchi, Chem. Mater., 2005, 17, 6666; d) W. Levason, S. D. Orchard and G. Reid, Chem. Commun., 2001, 427; e) W.-F. Liaw, C.-H. Lai, S.-J. Chiou,

40 Y.-C. Horng, C.-C. Chou, M.-C. Liaw, G.-H. Lee and S.-M. Peng, Inorg. Chem., 1995, 34, 3755.

24 A. Bondi, J. Phys. Chem., 1964, 68, 441.

25 P. Nagy, D. Szabó, I. Kapovits, Á. Kucsman, G. Argay and A. Kálmán, J. Mol. Struct., 2002, 606, 61.

4526 a) W. Nakanishi, S. Hayashi and S. Toyota, Chem. Commun., 1996, 371; b) W. Nakanishi, S. Hayashi, A. Sakaue, G. Ono and Y. Kawada, J. Am. Chem. Soc., 1998, 120, 3635; c) W. Nakanishi, S. Hayashi and S. Toyota, J. Org. Chem., 1998, 63, 8790; d) S. Hayashi and W. Nakanishi, J. Org. Chem., 1999, 64, 6688; e) W. Nakanishi,

$50 \quad$ S. Hayashi and T. Uehara, J. Phys. Chem. A, 1999, 103, 9906; f) W. Nakanishi, S. Hayashi and T. Uehara, Eur. J. Org. Chem., 2001, 3933; g) W. Nakanishi and S. Hayashi, Phosphorus Sulfur Silicon Relat. Elem., 2002, 177, 1833; h) W. Nakanishi, S. Hayashi and T. Arai, Chem. Commun., 2002, 2416; i) S. Hayashi and W. Nakanishi,

55 J. Org. Chem., 2002, 67, 38; j) W. Nakanishi, S. Hayashi and N. Itoh, Chem. Commun., 2003, 124; k) S. Hayashi, H. Wada, T. Ueno and W. Nakanishi, J. Org. Chem., 2006, 71, 5574; 1) S. Hayashi and W. Nakanishi, Bull. Chem. Soc. Jpn., 2008, 81, 1605.

27 A. L. Fuller, L. A. S. Scott-Hayward, Y. Li, M. Bühl, A. M. Z. 60 Slawin and J. D. Woollins, J. Am. Chem. Soc., 2010, 132, 5799.

28 CrystalClear 1.6: Rigaku Corporation, 1999. CrystalClear Software User's Guide, Molecular Structure Corporation, (c) 2000. J. W. P. Flugrath, Acta Crystallogr., Sect. D, 1999, D55, 1718.

29 SIR 97: A. Altomare, M. Burla, M. Camalli, G. Cascarano, C.

65 Giacovazzo, A. Guagliardi, A. Moliterni, G. Polidori and R. Spagna, J. Appl. Cryst., 1999, 32, 115.

30 DIRDIF99: P. T. Beurskens, G. Admiraal, G. Beurskens, W. P. Bosman, R. de Gelder, R. Israel, J. M. M. Smits, 1999. The DIRDIF99 program system, Technical Report of the Crystallography
31 CrystalStructure 3.8.1: Crystal Structure Analysis Package, Rigaku and Rigaku/MSC (2000-2006). 9009 New Trails Dr. The Woodlands TX 77381 USA.

32 SHELX97: G. M. Sheldrick, Acta Crystallogr., Sect. A, 2008, 64, $75 \quad 112$. 